\title{
Prisão cautelar e prazo razoável na jurisprudência dos Tribunais Superiores brasileiros
}

\author{
Pre-trial detention and reasonable time in the Brazilian \\ Superior Courts' jurisprudence
}

\author{
Daiana Ryu ${ }^{1}$ \\ Universidade de São Paulo - São Paulo/SP \\ daianaryu@gmail.com \\ lattes.cnpq.br/2739671258646549 \\ orcid.org/0000-0001-5920-0902
}

\begin{abstract}
Resumo: Considerando-se que a prisão é a medida cautelar mais gravosa do ordenamento jurídico brasileiro e sua aplicação tem sido banalizada pelo Poder Judiciário, ao haver cerca de $40 \%$ de presos provisórios nos estabelecimentos prisionais pátrios, tem-se como escopo da presente pesquisa a realização de um diagnóstico sobre o conteúdo das decisões dos Tribunais Superiores pátrios cujo objeto é a análise da razoabilidade da prisão cautelar. Em suma, pretende-se desvelar como são julgados os habeas corpus e os recursos ordinários em habeas corpus acerca da temática da duração da prisão cautelar, delineando-se o conteúdo de cada decisão e o método empregado para aferição da razoabilidade do prazo da prisão cautelar. Diante dos dados apresentados, conclui-se que há tendência nos Tribunais Superiores pátrios em manter prisões provisórias longas por meio de argumentação genérica, pautada em elementos vagos, o que corrobora certamente com a existência do alto índice de prisões cautelares nos estabelecimentos prisionais brasileiros.

PalaVRas-Chave: prazo razoável; prisão cautelar; jurisprudência.
\end{abstract}

1 Doutoranda e Mestre em Direito Processual Penal pela Universidade de São Paulo. Pós-graduada em Direito Penal Econômico pelo Instituto de Direito Penal Econômico Europeu da Faculdade de Direito da Universidade de Coimbra (2017). Possui graduação em Direito pela Universidade de São Paulo (2013). Membro do Corpo de Pareceristas do Boletim do Instituto Brasileiro de Ciências Criminais - IBCCRIM. 
ABSTRACT: Being the pre-trial detention the most severe precautionary measure and considering that the Judiciary has been trivializing its application, by totalizing approximately $40 \%$ of provisional prisoners in prisons custody, this present research aims to analyze the Superior Courts decisions when deliberating about the reasonableness of the precautionary prison. In conclusion, it is intended to expose how the precautionary prison duration has been deliberated on writs judgment, analyzing its content, along with the method applied when computing the precautionary prison term reasonableness. According to the statistics presented, the national Superior Courts demonstrate propensity on maintaining extended provisional prison by using generic assertion, validating the precautionary prison significant rate in Brazil.

KEYWORDS: reasonable time; pre-trial detention; jurisprudence.

SUMÁRIO: Introdução; 1. Doutrina do "não-prazo"; 1.1. Prazo razoável nos tratados internacionais de direitos humanos; 1.2. Critérios utilizados para aferição da razoabilidade do prazo da prisão cautelar no âmbito dos sistemas regionais de proteção dos direitos humanos; 1.3. Duração da prisão cautelar no processo penal brasileiro; 2. Metodologia 3. Análise dos julgados selecionados; 3.1. Tipo de instrumento processual, órgão julgador e relator; 3.2. Resultado do julgamento das liminares; 3.3. Pareceres do Ministério Público; 3.4. Resultado do julgamento dos casos; 3.5. Duração da prisão cautelar; 3.6. Tipos penais; 3.7. Critérios utilizados para aferição da razoabilidade do prazo; 4. Algumas notas sobre aferição da razoabilidade do prazo pelos Tribunais Superiores brasileiros; Considerações Finais; Referências.

\section{INTRODUÇÃo}

O processo penal é uma atividade que se desenvolve no tempo, havendo sempre um lapso temporal entre o pedido formulado e a respectiva resposta jurisdicional ${ }^{2}$. Por tal razão, tornou-se necessária a previsão

2 GRINOVER, Ada Pellegrini; FERNANDES, Antonio Scarance; GOMES FILHO, Antonio Magalhães. As nulidades no processo penal. 10. ed. São Paulo: Revista dos Tribunais, 2008, p. 331. 
no ordenamento jurídico de medidas com a finalidade de assegurar a utilidade e eficácia ${ }^{3}$ do seu provimento final ${ }^{4}$. Entre as diversas medidas cautelares previstas no processo penal brasileiro, a mais gravosa é a prisão provisória, eis que priva o acusado de um dos direitos mais relevantes antes de uma condenação definitiva, qual seja a liberdade.

O aumento significativo do encarceramento provisório no Brasil, tendo chegado a $40 \%$ do número total da população prisional brasileira no ano de $2016^{5}$, e a frequente notícia de prisões cautelares de duração exacerbada nos instigou à realização da presente pesquisa, a qual é fruto de dissertação de Mestrado apresentada à Faculdade de Direito do Largo de São Francisco ${ }^{6}$. Assim, considerando-se que o ordenamento jurídico pátrio adotou a doutrina do "não-prazo", não tendo previsto em seu bojo prazos máximos para duração do processo penal e da prisão preventiva, relegando-se às mãos do órgão julgador a determinação da razoabilidade/irrazoabilidade da duração da prisão cautelar, pretendeu-se desvelar, por meio deste estudo, o entendimento dos Tribunais Superiores acerca da temática em questão.

Em suma, tem-se como escopo traçar um diagnóstico das decisões proferidas pelo Superior Tribunal de Justiça e pelo Supremo Tribunal

3 BADARÓ, Gustavo Henrique. Processo penal. 5. ed. São Paulo: Revista dos Tribunais, 2017, p. 1002. Nessa esteira, explicando a tutela cautelar no âmbito do processo civil, José Roberto dos Santos Bedaque assevera que as medidas cautelares correspondem a "providências destinadas a eliminar os inconvenientes causados pelos efeitos do tempo necessário à plena cognição dos fatos e fundamentos desse suposto direito". (BEDAQUE, José Roberto dos Santos. Tutela cautelar e tutela antecipada: tutelas sumárias e de urgência. 5. ed. São Paulo: Malheiros, 2009, p. 85).

4 FERNANDES, Antonio Scarance. Processo penal constitucional. 4. ed. São Paulo: Revista dos Tribunais, 2005, p. 311.

5 Cf.: BRASIL. DEPARTAMENTO PENITENCIÁRIO NACIONAL (MINISTÉRIO DA JUSTIÇA). Levantamento Nacional de Informações Penitenciárias Infopen, Junho/2016. Brasília, 2017, p. 14. Disponível em: <http://justica. gov.br/sua-seguranca/seguranca-publica/analise-e-pesquisa/download/outras_publicacoes/pagina-3/24levantamento_nacional_info_penitenciarias. pdf/view>. Acesso em: 22 dez. 2017.

6 RYU, Daiana Santos. O direito ao desencarceramento do acusado preso cautelarmente, caso não seja julgado no prazo razoável: análise dos critérios utilizados para aferição do excesso de prazo da prisão cautelar na jurisprudência dos Tribunais Superiores brasileiros. Dissertação (Mestrado em Direito Processual) - Faculdade de Direito da Universidade de São Paulo, São Paulo, 2018. 
Federal cujo objeto era a aferição da razoabilidade do prazo da prisão cautelar. Desta feita, buscou-se verificar: (i) o conteúdo das decisões dos Tribunais Superiores brasileiros que versam sobre a duração da prisão cautelar, apresentando-se o órgão julgador, o tipo de instrumento processual, relator, tipos penais abrangidos; (ii) como tais Tribunais decidem os writs sobre tal matéria, aferindo-se as liminares, a possível influência do Ministério Público por meio de seus pareceres e o resultado do julgamento dos habeas corpus/recursos ordinários em habeas corpus; e (iii) o método empregado para aferição da razoabilidade do prazo da prisão cautelar.

Para tanto, dividiu-se o presente artigo em quatro tópicos: (1) será realizado breve escorço teórico acerca da doutrina do "não-prazo" no âmbito dos sistemas regionais de proteção de direitos humanos, bem como sobre a duração da prisão cautelar no processo penal brasileiro; (2) discorrer-se-á acerca da metodologia empregada na pesquisa empírica que será apresentada; (3) serão desvelados os resultados obtidos na pesquisa empírica; e (4) far-se-á uma análise acerca da aferição da razoabilidade do prazo da prisão cautelar pelos Tribunais Superiores pátrios.

\section{DOUTRINA DO "NÃO-PRAZO"}

\subsection{Prazo razoável nos tratados internacionais de direitos humanos}

Consoante aduz Placido Fernandez-Viagas Bartolome, o processo implica sempre desenvolvimento sucessivo de atos no tempo ${ }^{7}$. Nesse sentido, Daniel Pastor explica que o tempo é "elemento fundamental" do processo $^{8}$, tendo em vista que cada um de seus componentes possui o tempo como elemento constitutivo básico. Considerando-se a inerência da demora ao processo penal, exsurge a necessidade de se assegurar que esta não seja exacerbada, buscando-se evitar dilações indevidas no iter

7 FERNANDEZ-VIAGAS BARTOLOME, Placido. El derecho a un proceso sin dilaciones indebidas. Madrid: Civitas, 1994, p. 33.

8 PASTOR, Daniel R. El plazo razonable en el proceso del Estado de Derecho: una investigación acerca del problema de la excessiva duración del proceso penal y sus posibles soluciones. Buenos Aires: Ad-Hoc, Konrad - Adenauer Stiftung, 2002, p. 87. 
processual ${ }^{9}$. Por tal razão, a garantia da duração razoável da persecução penal tem sido alvo de constante preocupação em discussões no âmbito legislativo e doutrinário.

Diante da relevância da garantia da duração razoável da persecução penal, por meio do fenômeno da expansão dos direitos humanos, principalmente após o advento da Segunda Guerra Mundial, ela passou a ser incluída nos tratados internacionais de direitos humanos, tornando-se uma obrigação do Estado-parte assegurar a sua efetivação ${ }^{10}$.

No sistema regional europeu de direitos humanos, a Convenção para a Proteção dos Direitos Humanos e das Liberdades Fundamentais, celebrada em 1950, ampliou de forma significativa os instrumentos tradicionais de proteção da liberdade e da segurança pessoal. Trata-se do primeiro tratado internacional que acolheu expressamente a garantia da duração razoável do processo na forma mais usual de "prazo razoável”"11, preconizando em seu artigo 6.1 que: "Qualquer pessoa tem direito a que a sua causa seja examinada, equitativa e publicamente, num prazo razoável por um tribunal independente e imparcial, estabelecido pela lei, o qual decidirá, quer sobre a determinação dos seus direitos e obrigações de carácter civil, quer sobre o fundamento de qualquer acusação em matéria penal dirigida contra ela".

O artigo 5.3, por sua vez, trata especificamente da situação do acusado preso cautelarmente, dispondo que: "Qualquer pessoa presa ou detida nas condições previstas no parágrafo 1, alínea c), do presente artigo deve ser apresentada imediatamente a um juiz ou outro magistrado habilitado pela lei para exercer funções judiciais e tem direito a ser

9 CHIAVARIO, Mario. Procedure penali d'europa: Belgio, Francia, Germania, Inghilterra, Italia. Milano: CEDAM, 2001, p. 510.

10 GARCÍA-LÚBEN BARTHE, Paloma. El derecho a un proceso en un plazo razonable en el ámbito europeo. Análisis e interpretación del artículo 6.1 del Convenio Europeo de Derechos Humanos. In: ARMENTA DEU, Teresa; CALDERÓN CUADRADO, María Pía; OLIVA SANTOS, Andrés de la (coord.). Garantías fundamentales del proceso penal en el espacio judicial europeo. Madrid: Colex, 2007, p. 273.

11 PASTOR, Daniel R. El plazo razonable en el proceso del Estado de Derecho: una investigación acerca del problema de la excesiva duración del proceso penal y sus posibles soluciones. Buenos Aires: Ad-Hoc, Konrad - Adenauer Stiftung, 2002, p. 103. 
julgada num prazo razoável, ou posta em liberdade durante o processo. A colocação em liberdade pode estar condicionada a uma garantia que assegure o comparecimento do interessado em juízo".

No sistema regional interamericano de direitos humanos, a Convenção Americana de Direitos Humanos, celebrada em 1959, também trouxe dispositivos específicos acerca da duração do processo e da prisão cautelar. De um lado, o artigo 8.1 abrange o processo de forma ampla, enunciando que: "Toda pessoa tem direito a ser ouvida, com as devidas garantias e dentro de um prazo razoável, por um juiz ou tribunal competente, independente e imparcial, estabelecido anteriormente por lei, na apuração de qualquer acusação penal formulada contra ela, ou para que se determinem seus direitos ou obrigações de natureza civil, trabalhista, fiscal ou de qualquer outra natureza".

De seu turno, o artigo 7.5 estabelece que: “Qualquer pessoa tem direito a que a sua causa seja examinada, equitativa e publicamente, num prazo razoável por um tribunal independente e imparcial, estabelecido pela lei, o qual decidirá, quer sobre a determinação dos seus direitos e obrigações de carácter civil, quer sobre o fundamento de qualquer acusação em matéria penal dirigida contra ela”.

Embora os diplomas internacionais acima mencionados tenham trazido em seu bojo a garantia da duração razoável, não delimitaram quais seriam os prazos máximos em cada situação por eles tratada. Além disso, não estabeleceram critérios que definissem o momento da dilação indevida ${ }^{12}$, deixando a cargo do Estado-parte a determinação destes.

Ao se omitirem na fixação de prazos máximos para duração do processo e da prisão cautelar, a Convenção Europeia e a Convenção Americana de Direitos Humanos adotaram a denominada "doutrina do não-prazo"13. A tarefa de definir tal limite foi deixada, portanto, aos órgãos encarregados da interpretação das convenções na análise dos casos a eles submetidos. No sistema regional europeu, de início, à Comissão

12 NAKAHARADA, Carlos Eduardo Mitsuo. Prisão preventiva: direito à razoável duração e necessidade de prazo legal máximo. Dissertação (Mestrado em Direito Processual) - Faculdade de Direito da Universidade de São Paulo, São Paulo, 2015, p. 45.

13 BADARÓ, Gustavo Henrique; LOPES JÚNIOR, Aury. Direito ao processo penal no prazo razoável. Rio de Janeiro: Lumen Juris, 2006, p. 39 
Europeia, posteriormente, à Corte Europeia de Direitos Humanos. No sistema regional interamericano, à Comissão Americana e à Corte Interamericana de Direitos Humanos.

\subsection{CRITÉRIOS UtILIZAdos PARA AFERIÇÃo DA RAZOABILIDADE DO PRAZO DA PRISÃO CAUTELAR NO ÂMBITO DOS SISTEMAS REGIONAIS DE PROTEÇÃO DOS DIREITOS HUMANOS}

Diante da ausência da previsão de prazos fixos para duração do processo e da prisão cautelar na Convenção Europeia de Direitos Humanos, ao analisar o caso "Wemhoff v. Alemanha", no ano de 1968, a Comissão Europeia de Direitos Humanos formulou a doutrina dos sete critérios para aferição da razoabilidade do prazo da prisão cautelar de Karl Heinz Wemhoff, o qual permaneceu preso provisoriamente durante aproximadamente quatro anos ${ }^{14}$.

Em seu parecer, a Comissão fez menção aos seguintes critérios: (i) a duração da detenção em si mesma; (ii) o tempo de prisão preventiva à luz da natureza do delito, da pena cominada e da possível reprimenda a ser aplicada em caso de condenação; (iii) os efeitos da detenção sobre a pessoa do recluso, de ordem moral, material e outros; (iv) a conduta do acusado em relação à fase investigativa e ao processo (ele contribuiu, de qualquer forma, para a demora, ou ainda, ofereceu fiança ou outras garantias para a liberdade provisória?); (v) a dificuldade de investigação do caso, seja em virtude da complexidade da causa, seja pela quantidade de testemunhas ou corréus, ou pelas dificuldades probatórias; (vi) o modo como as investigações foram conduzidas, englobando o sistema investigatório ou condutas das autoridades responsáveis pelo procedimento e (vii) a conduta das autoridades judiciais envolvidas ${ }^{15}$.

14 EUROPEAN COURT OF HUMAN RIGHTS. Court (Chamber). Caso Wemhoff v. Alemanha (Application no 2122/64). Julgado em: 27 de junho de 1968. Disponível em: <http://hudoc.echr.coe.int/eng\#\{“itemid":[“001-57595”]\}>. Acesso em: 04 jul. 2018.

15 EUROPEAN COURT OF HUMAN RIGHTS. Court (Chamber). Caso Wemhoff vs. Alemanha (Application no 2122/64). Julgado em: 27 de junho de 1968. Disponível em: <http://hudoc.echr.coe.int/eng\#\{“itemid":[“001-57595”]\}>. Acesso em: 01 set. 2017. 
Não obstante o esforço da Comissão Europeia em ver reconhecida a violação à garantia da duração razoável da prisão cautelar, o Tribunal Europeu de Direitos Humanos, rechaçando a doutrina dos sete critérios, não verificou nenhuma violação à Convenção. No entanto, a dificuldade de interpretação do conceito do prazo razoável levou a Corte Europeia de Direitos Humanos a utilizar critérios objetivos para aferição da razoabilidade do prazo nos casos a ela submetidos. Assim, a partir dos anos oitenta, passou a utilizar rol "mais enxuto"16, denominado "teoria dos três critérios”, quais sejam: a) complexidade do caso, b) atividade processual do interessado (imputado) e c) conduta das autoridades judiciárias ${ }^{17}$.

Esse rol de critérios foi consolidado no caso "Foti e outros v. Itália"18, julgado pela Corte Europeia de Direitos Humanos em 10 de dezembro de $1982^{19}$. Entretanto, em decisões mais recentes do Tribunal Europeu de Direitos Humanos, como no caso "Taran v. Ucrânia”" ${ }^{20}$ julgado em 2013, nota-se a confirmação do entendimento consolidado na década de $1980^{21}$, eis que a

16 BADARÓ, Gustavo Henrique; LOPES JÚNIOR, Aury. Direito ao processo penal no prazo razoável. Rio de Janeiro: Lumen Juris, 2006, p. 40.

17 Cf. BARTOLE, Sergio; CONFORTI, Benedetto; RAIMONDI, Guido. Commentario alla Convenzione Europea per la tutela dei diritti dell'uomo e delle libertà fondamentali. Milano: CEDAM, 2001, p. 41; BARRETO, Ireneu Cabral. A Convenção Europeia de Direitos do Homem - anotada. 5. ed. Coimbra: Almedina, 2015, A Convenção Europeia de Direitos Humanos, item 4.2.3, posição 77, E-book.

EUROPEAN COURT OF HUMAN RIGHTS. Court (Chamber). Caso Foti e outros vs. Itália. Julgado em: 10 de dezembro de 1982. Disponível em: <http:// hudoc.echr.coe.int/eng\#\{ "fulltext”:[“\”CASE OF FOTI AND OTHERS v. ITALY \"”,",sort":["kpdate Descending"],"documentcollectionid2":[“JUDGMENTS”],"itemid”:[“001-165168”]\}>. Acesso em: 03 set. 2017.

PASTOR, Daniel R. El plazo razonable en el processo del Estado de Derecho: una investigación acerca del problema de la excesiva duración del proceso penal y sus posibles soluciones. Buenos Aires: Ad-Hoc, Konrad- Adenauer Stiftung, 2002, p. 153.

EUROPEAN COURT OF HUMAN RIGHTS. Court (Chamber). Caso Taran vs. Ucrânia. Julgado em: 17 de outubro de 2013. Disponível em: <https://hudoc. echr.coe.int/eng\#\{“fulltext”:[“\”CASE OF TARAN v. UKRAINE \"”],"sort”:["kpdate Descending"],"documentcollectionid2":["JUDGMENTS"],"itemid”:[“001-126909”]\}>. Acesso em: 03 set. 2017.

Cf. BARROS, Flaviane Magalhães. O tempo devido do processo penal e a influência das decisões da CADH no Brasil. In: MALAN, Diogo; PRADO, Geraldo (coord.). Processo penal e direitos humanos. Rio de Janeiro: Lumen Juris, 2012, p. 67. Entre outros, verificar: Motta v. Itália, julgado em 19 fev. 1991; 
Corte, ao aplicar a teoria dos três critérios, entendeu que as circunstâncias do caso não indicavam complexidade que justificasse a demora excessiva do término da persecução penal, tendo condenado a Ucrânia por violação ao artigo 6.1 da Convenção Europeia de Direitos Humanos.

Segundo José Carlos Remotti Carbonell, seguindo o caminho percorrido pela Corte de Estrasburgo, a Comissão e a Corte Interamericana de Direitos Humanos, em suas manifestações ${ }^{22}$, buscam aplicar a teoria dos três critérios. Assim, realizam uma análise global de cada caso concreto, averiguando, em primeiro lugar, se a causa é complexa ou simples; em segundo lugar, se o comportamento do interessado é protelatório ou diligente e, em terceiro lugar, se as autoridades estatais estão empregando os meios materiais e pessoais adequados e suficientes para o exercício da função jurisdicional ${ }^{23}$.

No que tange à aplicação de cada critério, segundo Ireneu Cabral Barreto, no âmbito do sistema regional europeu de direitos humanos, a complexidade da causa é a circunstância mais invocada para se explicar a delonga do processo, sendo preenchida pelo número de pessoas envolvidas, múltiplas questões de fato ou de direito suscitadas ou pelo seu volume ${ }^{24}$. Referido critério é utilizado para justificar a morosidade processual advinda das particularidades presentes em determinado caso concreto, que podem decorrer tanto dos fatos da causa quanto do direito a ela aplicável ${ }^{25}$.

Ruiz Mateos v. Espanha, julgado em 23 Jun. 1993; Kudla v. Polônia, julgado em 26 out. 2000; Kalashnikov v. Rússia, julgado em 15 jul. 2002; Gubkin v. Rússia, julgado em 23 abr. 2009; Yankov v. Bulgária, julgado em 11 mar. 2004; Vayic v. Turquia, julgado em 20 jun. 2006; Riccardi v. Romênia, julgado em 03 abr. 2012; Taran v. Ucrânia, julgado em 17 out. 2013 e Grujović v. Sérvia, julgado em 21 jul. 2015.

Cf. Caso Tibi vs. Equador; Caso Acosta Calderón vs. Equador; Caso López Álvarez vs. Honduras; Caso Bayarri vs. Argentina; Caso Barreto Leiva vs. Venezuela; Caso Suárez Rosero vs. Equador; Caso Genie Lacayo vs. Nicarágua. CARBONELL, José Carlos Remotti. La Corte Interamericana de Derechos $\mathrm{Hu}$ manos. Estructura, funcionamiento y jurisprudencia. Barcelona: Instituto Europeo de Derecho, 2013, p. 357-358.

24 BARRETO, Ireneu Cabral. A Convenção Europeia de Direitos do Homem - anotada. 5. ed. Coimbra: Almedina, 2015, Assim, os interesses relacionados com, item 6.3, posição 37. E-book.

25 Cf. NICOLA, Francesco de Santis di. Ragionevole durata del processo e rimedio effetivo. Napoli: Jovene, 2013, p. 168. 
Com relação ao comportamento da parte, Gustavo Henrique Badaró e Aury Lopes Júnior aduzem que se trata de assunto com destaque especial na doutrina e na jurisprudência para aferição da duração razoável do processo $^{26}$. Isto porque, no processo penal, há o dilema referente ao equilíbrio entre o direito a não dilação indevida e ao tempo necessário para defesa efetivar as garantias processuais penais que lhe pertencem ${ }^{27}$. Assim, somente restará configurada a violação da garantia da duração razoável do processo, por parte do imputado, se no caso concreto existirem atos manifestamente protelatórios ${ }^{28}$, como por exemplo: a "reiteração de adiamentos de audiências requeridos pela parte, ora em razão de alegação de saúde quando o problema não impede o comparecimento, ora em razão de frequentes trocas de advogados" ${ }^{29}$ e "a hipótese de fuga do acusado, impedindo ou retardando o julgamento" 30 .

Quanto à conduta das autoridades judiciárias, vale salientar que considerando a responsabilidade estatal em respeitar as garantias do devido processo penal, as dificuldades que decorrem de fatores estruturais, apresentadas pelo Poder Judiciário e pelos órgãos que compõem o sistema de justiça, não são reconhecidas pelos Tribunais Internacionais de Direitos Humanos como justificativas idôneas a escusar o Estado de sua obrigação de envidar esforços para garantir a duração razoável da persecução penal ${ }^{31}$. Dessa forma, a precariedade física e a deficiência de pessoal dos órgãos públicos não são aptas a eximir o Estado da efetivação da garantia da duração razoável do processo ${ }^{32}$.

26 BADARÓ, Gustavo Henrique; LOPES JÚNIOR, Aury. Direito ao processo penal no prazo razoável. Rio de Janeiro: Lumen Juris, 2006, p. 62-63.

27

28

29

30

31 Constituição Federal e o Pacto de São José da Costa Rica. 2. ed. São Paulo: Atlas, 2015, p. 347-348.

32 GARCÍA-LÚBEN BARTHE, Paloma. El derecho a un proceso en un plazo razonable en el ámbito europeo. Análisis e interpretación del artículo 6.1 del Convenio Europeo de Derechos Humanos. In: ARMENTA DEU, Teresa; 
Diante do exposto, importante destacar que, a princípio, a utilização dos critérios parece permitir um "verdadeiro balizamento interpretativo"33 à doutrina do "não-prazo". Para Alexandre Morais da Rosa e Sylvio Lourenço da Silveira Filho, o emprego de "standards" na análise de cada caso concreto diminui o arbítrio judicial e possibilita a solução dos problemas referentes ao tema em razão de sua complexidade ${ }^{34}$. No entanto, de outro vértice, Alberto Silva Franco sustenta que através da tentativa de se preencher a ideia de prazo razoável por meio de tais padrões jurisprudenciais, "corre-se o risco de se substituir um conceito um tanto vago por outro de maior vagueza" 35 .

Embora tenha recebido diversas críticas pela doutrina processual nacional e internacional ${ }^{36}$, fato é que o rol de critérios desenvolvido no sistema regional europeu de direitos humanos tem sido aplicado por tribunais de diversos países, tendo, inclusive, servido de influência aos Tribunais Superiores brasileiros, consoante se explanará a seguir.

\subsection{DuRAÇ̃̃o DA PRISÃo CAUTELAR NO PROCESSO PENAL BRASILEIRO}

Embora a garantia da duração razoável do processo esteja prevista expressamente no artigo $5^{\circ}$, inciso LXXVIII, da Constituição da República, no sistema jurídico pátrio não foram fixados prazos máximos ${ }^{37}$ para a duração da persecução penal e da prisão preventiva.

CALDERÓN CUADRADO, María Pía; OLIVA SANTOS, Andrés de la (coord.). Garantías fundamentales del proceso penal en el espacio judicial europeo. Madrid: Colex, 2007, p. 284.

33 ROSA, Alexandre Morais da; SILVEIRA FILHO, Sylvio Lourenço da. Medidas compensatórias da demora jurisdicional: a efetivação do direito fundamental à duração razoável do processo penal. Rio de Janeiro: Lumen Juris, 2014, p. 46. Ibidem, p. 46.

FRANCO, Alberto Silva. Prazo razoável e o estado democrático de direito. Boletim IBCCRIM, São Paulo, v. 13, n. 152, p. 6-7, jul. 2005, p. 7.

36 Por exemplo: PASTOR, Daniel R. El plazo razonable en el proceso del Estado de Derecho: una investigación acerca del problema de la excesiva duración del proceso penal y sus posibles soluciones. Buenos Aires: Ad-Hoc, KonradAdenauer Stiftung, 2002, p. 167

37 FRANCO, Alberto Silva. Prazo razoável e o estado democrático de direito. Boletim IBCCRIM, São Paulo, v. 13, n. 152, p. 6-7, jul. 2005, p. 6. 
Assim, tendo nosso sistema adotado a "doutrina do não-prazo", ficou a cargo do órgão julgador a delimitação da razoabilidade do prazo em cada caso concreto.

Em razão de tal lacuna legislativa, antes da reforma do Código de Processo Penal em 2008, a jurisprudência pátria por muito tempo utilizou a denominada "regra dos 81 dias". A partir da soma dos prazos para a prática dos diversos atos que compunham a persecução penal até a sentença de primeiro grau, foi estabelecido o prazo de 81 (oitenta e um) dias para o encerramento da instrução criminal de processos que envolvessem réus presos ${ }^{38}$. Caso este período fosse superado, estando o acusado preso e ainda não tivesse sido prolatada a sentença de primeiro grau, o excesso de prazo estaria configurado, impondo-se sua soltura, por exemplo, por meio de habeas corpus, nos termos do artigo 648, inciso II, do Código de Processo Penal ${ }^{39}$.

Importante destacar que o critério dos 81 (oitenta e um) dias, segundo leciona Antonio Scarance Fernandes, de forma gradativa, passou a admitir exceções, tais como: (i) o tempo de oitenta e um dias era exigível apenas para o enceramento da instrução criminal; (ii) a justificação do excesso de prazo em razão de vários motivos (grande número de acusados, complexidade da causa, necessidade de expedição de cartas precatórias, instauração de incidentes mentais); (iii) a declaração da inexistência de constrangimento ilegal quando o excesso correspondesse a diligências de interesse da defesa; (iv) a afirmação de que o excesso deveria ser averiguado em cada caso concreto de acordo com um critério de razoabilidade ${ }^{40}$. Dessa forma, referido período foi sendo relegado à condição de marco para a verificação do excesso, sendo que sua superação não significava, por si

38 O critério dos 81 dias englobava a soma dos seguintes prazos: inquérito - 10 dias (art. 10); denúncia - 5 dias (art. 46); defesa prévia - 3 dias (art. 395); inquirição de testemunhas - 20 dias (art. 401); requerimento de diligências - 2 dias (art. 499); prazo para despacho do requerimento: 10 dias (art. 499); alegações das partes: 6 dias (art. 500); diligências ex officio: 5 dias (art. 502); sentença: 20 dias (art. 502, c.c. art. 800, $\$ 3^{\circ}$ ).

39 Cf. BADARÓ, Gustavo Henrique; LOPES JÚNIOR, Aury. Direito ao processo penal no prazo razoável. Rio de Janeiro: Lumen Juris, 2006, p. 102.

40 FERNANDES, Antonio Scarance. Processo penal constitucional. 4. ed. São Paulo: Revista dos Tribunais, 2005, p. 125. 
só, o constrangimento ilegal, o qual deveria ser aferido em cada caso concreto à luz do critério da razoabilidade ${ }^{41}$.

No mais, o critério dos 81 (oitenta e um) dias tornou-se obsoleto com a reforma do Código de Processo Penal, realizada pela Lei $\mathrm{n}^{\circ}$ $11.719 / 2008^{42}$, a qual uniformizou os procedimentos penais, modificando os prazos para realização dos atos processuais, os quais passaram a variar entre 105 (cento e cinco) e 125 (cento e vinte e cinco) dias, podendo ser ampliados em razão dos incidentes processuais ${ }^{43}$. A partir de tal reforma, a jurisprudência passou a se desvencilhar ainda mais da orientação de se considerar como parâmetro para a duração da prisão cautelar os prazos estabelecidos pelo legislador para o término da instrução criminal $^{44}$.

Nessa linha, Andrey Borges de Mendonça assevera que a contagem dos prazos foi sendo relativizada pela jurisprudência, passando-se a considerar que a mera contagem aritmética dos prazos não seria suficiente, sendo necessário analisar a questão segundo as circunstâncias do caso concreto e o princípio da razoabilidade ${ }^{45}$. Nessa senda, no HC

41 Sobre a noção de razoabilidade, compartilhamos da visão apresentada por Thaís Aroca Datcho Lacava: embora alguns autores afirmem que proporcionalidade e razoabilidade se confundam, "a noção de razoabilidade é mais ampla, contendo em si a ideia de justiça, sendo que cada país desenvolveu uma linha de pensamento de forma a fixar os contornos deste princípio. Só o que é proporcional será razoável, porque pode não ser adequado ou necessário para alcançar um determinado fim. É o que conclui PIMENTA OLIVEIRA, referindo que a análise da razoabilidade pode ser aferida com base e outros instrumentos, além da proporcionalidade, o que demonstra que esta teria um âmbito um pouco mais ampliado em relação à proporcionalidade”. (LACAVA, Thaís Aroca Datcho. A garantia da duração razoável da persecução penal. Dissertação (Mestrado em Direito Processual) - Faculdade de Direito da Universidade de São Paulo, São Paulo, 2009, p. 92)

42 NAKAHARADA, Carlos Eduardo Mitsuo. Prisão preventiva: direito à razoável duração e necessidade de prazo legal máximo. Dissertação (Mestrado em Direito Processual) - Faculdade de Direito da Universidade de São Paulo, São Paulo, 2015, p. 120.

43 MENDONÇA, Andrey Borges de. Prisão e outras medidas cautelares pessoais. São Paulo: Método, 2011, p. 301.

44 SANGUINÉ, Odone. Prisão cautelar, medidas alternativas e direitos fundamentais. Rio de Janeiro: Forense, 2014, p. 495.

45 MENDONÇA, Andrey Borges de. Prisão e outras medidas cautelares pessoais. São Paulo: Método, 2011, p. 302. 
$\mathrm{n}^{\mathrm{o}}$ 413.384/SP, julgado em 10 de outubro de 2017, a Quinta Turma do Superior Tribunal de Justiça asseverou que:

(...) quanto ao apontado excesso de prazo na formação da culpa, ressalta-se que os prazos processuais não possuem características de fatalidade e de improrrogabilidade, não se ponderando mera soma aritmética de tempo para os atos processuais. A propósito, esta Corte Superior firmou jurisprudência no sentido de se considerar o juízo de razoabilidade para eventual constatação de constrangimento ilegal ao direito de locomoção decorrente de excesso de prazo $(. . .)^{46}$

Destaque-se que os Tribunais Superiores pátrios, diante da ausência de prazos máximos na legislação brasileira para a duração da persecução penal e da prisão cautelar, à luz da razoabilidade, vêm adotando a aplicação de critérios em cada caso concreto. Em especial, têm lançado mão dos critérios da complexidade da causa, do comportamento da parte e da conduta das autoridades judiciárias, a fim de verificar se houve ou não constrangimento ilegal motivado pelo excesso de prazo da custódia provisória ${ }^{47}$. Assim, passaram a considerar os prazos eventualmente fixados na legislação pátria como simples referencial ${ }^{48}$, entendendo que não configura constrangimento ilegal a dilação desse prazo para a conclusão da instrução do processo nos casos justificados por meio do "critério da razoabilidade" ${ }^{49}$.

\section{Metodologia}

No presente item, será apresentada a metodologia utilizada na colheita e na análise dos dados ${ }^{50}$ aqui estudados. Considerando-se que a estatística

46 STJ, HC nº 413.384-SP, Quinta Turma, Relator: Min. Felix Fischer, J. 10/10/2017.

47 Nesse sentido, conferir: GIACOMOLLI, Nereu José. Prisão, liberdade e as cautelares alternativas ao cárcere. São Paulo: Marcial Pons, 2013.

48 Ibidem, p. 479.

49 BÁRTOLI, Márcio Orlando. O critério da razoabilidade (jurisprudência comentada). Revista Brasileira de Ciências Criminais, São Paulo, v. 1, n. 3, p. 184187, jul./set. 1993.

50 Nessa senda, importa consignar que a metodologia tem como função: “ajudar o analista a refletir para adaptar o mais possível seus métodos, as modalidades 
revela com maior precisão os resultados que se pretende expor, por meio da análise quantitativa, buscar-se-á aferir o conteúdo das decisões dos Tribunais Superiores pátrios cujo objeto corresponda à alegação de constrangimento ilegal por excesso de prazo da prisão cautelar. Desta feita, pretende-se analisar estatisticamente: (i) resultado do julgamento das liminares; (ii) teor dos pareceres do Ministério Público; (iii) resultado do julgamento dos casos analisados; (iv) duração da prisão cautelar; (v) tipos penais e (vi) critérios utilizados para aferição da razoabilidade do prazo da prisão cautelar.

Para a realização desta pesquisa empírica, tendo em vista ser inviável analisar todas as decisões do Superior Tribunal de Justiça e do Supremo Tribunal Federal acerca do tema aqui proposto, foi necessária a formação de uma amostra. Assim, por meio da seleção de determinada parcela das decisões dos Tribunais Superiores brasileiros sobre a aferição da razoabilidade do prazo da prisão cautelar é que o presente estudo se desenvolverá.

Segundo Juliana Bonacorsi Palma, Marina Feferbaum e Victor Marcel Pinheiro, para conferir um maior direcionamento à pesquisa de jurisprudência deve-se lançar mão dos "recortes jurisprudenciais" ${ }^{51}$. Estes correspondem a todas as estratégias para delimitação do tema, sendo que os mais recorrentes são os institucionais, temáticos, processuais e os temporais ${ }^{52}$, os quais serão utilizados na tarefa de melhor restringir a amostra do presente estudo.

Em relação ao recorte institucional, justifica-se a escolha das decisões do Supremo Tribunal Federal ${ }^{53}$ e do Superior Tribunal de Jus-

de amostragem e a natureza dos dados, ao objeto de sua pesquisa em vias de construção". (PIRES, Álvaro. Amostragem e pesquisa qualitativa: ensaios teóricos e metodológicos. In: POUPART, Jean; DESLAURIERS, Jean-Pierre; GROULX, Lionel-H; LAPERRIERE, Anne; MAYER, Robert; PIRES, Alvaro (org.). A pesquisa qualitativa: enfoques epistemológicos e metodológicos. Tradução Ana Cristina Nasser. Petrópolis: Vozes, 2008, p. 156)

51 PALMA, Juliana Bonacorsi de; FEFERBAUM, Marina; PINHEIRO, Victor Maciel. Meu trabalho precisa de jurisprudência? Como posso utilizá-la? In: QUEIROZ, Rafael Mafei Rabelo. FEFERBAUM, Marina (Coord.). Metodologia jurídica: um roteiro prático para trabalhos de conclusão de curso. São Paulo: Saraiva, 2012, p. 144.

52 Ibidem, p. 144.

53 Para Miguel Reale, a jurisprudência do Supremo Tribunal Federal "tem mais força, porquanto, aos poucos, os juízes vão se ajustando aos julgados dos 
tiça, eis que correspondem, respectivamente, ao órgão com competência precípua de guardar a Constituição Federal, nos termos do artigo 102, da Constituição da República de $1988^{54}$, cabendo-lhe a função de órgão cúpula do Poder Judiciário ${ }^{55}$ e ao órgão que tem como atribuição principal "o controle da inteireza positiva, da autoridade e da uniformidade de interpretação da lei federal" ${ }^{56}$, nos termos do artigo 105, inciso III, alíneas “a”, "b" e "c", da Constituição da República de 1988. Assim, tendo em vista a relevância dessas Cortes na uniformização da jurisprudência pátria, influenciando os tribunais locais, de rigor a análise de suas decisões para verificação da aplicação da doutrina do "não-prazo" em âmbito nacional.

Considerando que o recorte temático corresponde à própria delimitação do tema ${ }^{57}$, conforme já explicitado, o foco será a pesquisa das decisões do Supremo Tribunal Federal e do Superior Tribunal de Justiça quanto à aferição da razoabilidade do prazo da prisão cautelar.

No que tange ao recorte temporal, a escolha foi baseada no marco representado pela inserção da garantia da duração razoável do processo na Constituição da República de 1988, de forma expressa, por meio da Emenda Constitucional $n^{0} 45 / 2004^{58}$. Isto porque a reforma por ela efetuada, entre outros objetos, teve como escopo introduzir um dispositivo que proporcionasse celeridade, eficiência e segurança ao Poder Judiciário $^{59}$. Ainda que tal garantia já estivesse presente no ordenamento jurídico

órgãos superiores”. (REALE, Miguel. Lições preliminares de Direito. 24. ed. São Paulo: Saraiva, 1999, p. 174)

Dispõe o caput do artigo 102, da Constituição da República de 1988: "Compete ao Supremo Tribunal Federal, precipuamente, a guarda da Constituição (...)”. SILVA, José Afonso da. Curso de Direito Constitucional Positivo. 30. ed. São Paulo: Malheiros, 2007, p. 559.

56 Ibidem, p. 573.

57 PALMA, Juliana Bonacorsi de; FEFERBAUM, Marina; PINHEIRO, Victor Maciel. Meu trabalho precisa de jurisprudência? Como posso utilizá-la? In: QUEIROZ, Rafael Mafei Rabelo. FEFERBAUM, Marina (Coord.). Metodologia jurídica: um roteiro prático para trabalhos de conclusão de curso. São Paulo: Saraiva, 2012, p. 145.

BADARÓ, Gustavo Henrique. Processo penal. 5. ed. São Paulo: Revista dos Tribunais, 2017, p. 79.

59 Segundo a Exposição de Motivos da Emenda Constitucional $n^{0} 45 / 2004$, por meio de diagnóstico realizado sobre o Poder Judiciário nacional: “a Justiça brasileira é cara, morosa e eivada de senões que são obstáculos a que 
brasileiro por força da incorporação da Convenção Americana de Direitos Humanos, a inclusão do inciso LXXVIII no artigo $5^{\circ}$ da Constituição da República tornou inequívoco o seu status constitucional ${ }^{60}$.

Assim, considerando-se a data do início da vigência de referida emenda, foi escolhido como marco inicial do espaço amostral o dia 30/12/2004. De outro lado, tendo em vista o objetivo de se demonstrar a evolução interpretativa da jurisprudência dos Tribunais Superiores pátrios quanto à aplicação dos critérios utilizados para aferição da razoabilidade do prazo, bem como a necessidade de se trazer um panorama atual das decisões proferidas por tais Cortes, foi determinada a data de 30/12/2016 como marco final desta pesquisa empírica.

Com relação ao recorte processual, por meio do qual se elege um instrumento processual específico para ser trabalhado na pesqui$\mathrm{sa}^{61}$, optou-se utilizar as decisões proferidas em sede de habeas corpus e de recursos ordinários constitucionais em habeas corpus. Essa escolha justifica-se em razão da delimitação do tema aqui tratado, abrangendo, portanto, somente casos em que há restrição da liberdade do acusado.

Delimitados os recortes jurisprudenciais, faz-se necessário explicitar as palavras-chave que nortearam a pesquisa dos acórdãos. Assim, no campo "Pesquisa livre" dos sítios eletrônicos do Supremo Tribunal Federal $^{62}$ e do Superior Tribunal de Justiça ${ }^{63}$, foi inserida a expressão

os jurisdicionados recebam a prestação que um Estado democrático lhe deve". (CÂMARA DOS DEPUTADOS. Exposição dos motivos da Emenda $\mathrm{n}^{\mathrm{o}}$ 45/2004. Disponível em: <http://www2.camara.leg.br/legin/fed/emecon/2004/emendaconstitucional-45-8-dezembro-2004-535274-exposicaodemotivos-149264-pl.html>. Acesso em: 31 out. 2017)

KOEHLER, Frederico Augusto Leopoldino. A razoável duração do processo. 2. ed. Salvador: Juspodivum, 2013, p. 47.

61 PALMA, Juliana Bonacorsi de; FEFERBAUM, Marina; PINHEIRO, Victor Maciel. Meu trabalho precisa de jurisprudência? Como posso utilizá-la? In: QUEIROZ, Rafael Mafei Rabelo. FEFERBAUM, Marina (Coord.). Metodologia jurídica: um roteiro prático para trabalhos de conclusão de curso. São Paulo: Saraiva, 2012, p. 146.

62 Cumpre asseverar que a coleta dos acórdãos da presente pesquisa foi realizada entre os dias 05 e 10 de março de 2017, no sítio eletrônico do Supremo Tribunal Federal: <www.stf.jus.br.>.

63 A coleta dos acórdãos do Superior Tribunal de Justiça foi realizada entre os dias 11 e 20 de março de 2017, no sítio eletrônico: <www.stj.jus.br>. 
"prisão e prazo e razoável” " 4 limitando-se o período em 30/12/2004 a 30/12/2016. Para conferir maior abrangência à pesquisa, optou-se por não qualificar a prisão como "cautelar" ou "provisória”, visandose a abranger as prisões em flagrante que se perpetuavam durante o processo, antes da reforma do Código de Processo Penal realizada pela Lei $n^{\circ} 12.403 / 2011$.

Ao final desse procedimento de busca nos endereços eletrônicos dos Tribunais Superiores pátrios, obteve-se o seguinte resultado: 244 (duzentos e quarenta e quatro) acórdãos prolatados pelo Supremo Tribunal Federal e 809 (oitocentos e nove) acórdãos prolatados pelo Superior Tribunal de Justiça. Assim, a pesquisa abrangeu o número total de 1.053 (mil e cinquenta e três) acórdãos.

Considerando-se que a escolha dos julgados não deve se esgotar com os resultados fornecidos pela pesquisa online de um tribunal, consoante aduz Rafael Mafei Rabelo Queiroz, é preciso examinar a pertinência dos resultados gerados pelo sistema ${ }^{65}$. Desse modo, do número total de acórdãos encontrados foi necessário o descarte de alguns julgados que não interessavam aos fins deste trabalho, quais sejam: (i) aqueles que não correspondiam ao julgamento de habeas corpus e a recurso ordinário em habeas corpus; (ii) aqueles que não tinham como escopo a aferição da razoabilidade do prazo da prisão cautelar; (iii) os casos em que o paciente não estivesse preso; (iv) os casos em que a ordem foi julgada prejudicada, sem que houvesse sido discutido o tema do excesso de prazo; e (v) os casos em que não foi discutida matéria de direito penal.

Dessa forma, tendo em vista a exclusão dos casos supramencionados, o espaço amostral do presente trabalho consolidou-se no número

64 Após diversas tentativas na formulação de palavras-chaves, reputou-se que a expressão "prisão e prazo e razoável” foi a melhor opção para esta pesquisa, eis que abarcou o maior número de casos relativos ao tema aqui tratado, contribuindo para a formação de uma amostra que representasse de modo mais verossímil o entendimento firmado pelos Tribunais Superiores brasileiros, embora se reconheça a possibilidade da existência de julgados que não foram disponibilizados no site.

65 QUEIROZ, Rafael Mafei Rabelo. Monografia jurídica: passo a passo. São Paulo: Método, 2015, p. 102. 
de 944 (novecentos e quarenta e quatro) acórdãos, que integraram efetivamente o banco de dados da pesquisa quantitativa ${ }^{66}$.

\section{Análise dos julgados Selecionados}

\subsection{TIPO DE INSTRUMENTO PROCESSUAL, ÓRGÃO JULGADOR E RELATOR}

No que tange ao Superior Tribunal de Justiça, cumpre salientar que dos 737 (setecentos e trinta e sete) acórdãos selecionados, 595 (quinhentos e noventa e cinco) correspondem a habeas corpus e 142 (cento e quarenta e dois) a recursos ordinários em habeas corpus. Desse conjunto, 511 (quinhentos e onze) foram julgados pela Quinta Turma, ou seja, 69\% dos casos analisados e 226 (duzentos e vinte e seis) foram apreciados pela Sexta Turma, ou seja, 30\% de tal montante.

De se consignar que no período aqui considerado, qual seja de $30 / 12 / 2004$ a 30/12/2016, aferiu-se que 22 (vinte e dois) ministros participaram da relatoria do julgamento dos casos na Quinta Turma e que 21 (vinte e um) foram relatores no julgamento dos casos na Sexta Turma. Assim, 43 (quarenta e três) ministros foram responsáveis pela relatoria dos casos selecionados no presente trabalho, do que se pode inferir, prima facie, a possibilidade de se examinar as diversas linhas interpretativas dessa Corte.

Quanto ao Supremo Tribunal Federal, dos 207 (duzentos e sete) acórdãos selecionados, 198 (cento e noventa e oito) correspondem a habeas corpus e 09 (nove) a recursos ordinários em habeas corpus. Do total da amostra, 109 (cento e nove) foram julgados pela Primeira Turma, ou seja, $52 \%$ dos casos, e 97 (noventa e sete) foram apreciados pela Segunda Turma, ou seja, 46\% de tal montante. Por fim, 01 (um) acórdão foi julgado pelo Órgão Pleno do Supremo Tribunal Federal ${ }^{67}$.

66 Importante deixar claro que apesar de que, prima facie, o número de 944 (novecentos e quarenta e quatro) acórdãos pareça elevado, ao longo da pesquisa, chegou-se à conclusão de que as decisões, tanto do Superior Tribunal de Justiça quanto do Supremo Federal, são bastante padronizadas, principalmente em relação ao relator, o que tornou factível a análise desse espaço amostral. HC 85237/DF, Tribunal Pleno, Rel. Min.Celso de Mello, J. 17/03/2005. 
No que tange à relatoria dos acórdãos do Supremo Tribunal Federal, ao longo do período analisado, qual seja, de 30/12/2004 a 30/12/2016, verificou-se que 12 (doze) ministros participaram da relatoria do julgamento dos casos na Primeira Turma e que 12 (doze) foram relatores no julgamento dos casos na Segunda Turma. Assim, considerando a participação de alguns ministros como relatores em casos julgados nas duas Turmas, 18 (dezoito) ministros foram responsáveis pela relatoria dos casos selecionados no presente trabalho.

\title{
3.2. RESULtADO DO JULGAMENTO DAS LIMINARES
}

No que tange às liminares ${ }^{68}$ julgadas pelo Superior Tribunal de Justiça, verificou-se que em 572 (quinhentos e setenta e dois) acórdãos, o tribunal indeferiu-as, o que representa $78 \%$ do número total de casos analisados. Ademais, verificou-se que apenas 21 (vinte e uma) liminares foram deferidas, o que corresponde a somente $3 \%$ desse montante, consoante se verifica do gráfico abaixo:

GRÁFICO 01 - Liminares (Superior Tribunal de Justiça)

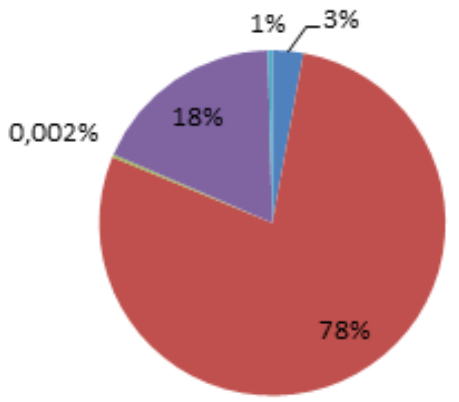

\author{
Deferidas \\ Indefe ridas \\ Deferidas parcialmente \\ Sem pedido de lim inar \\ Prejudicadas
}

Fonte: RYU, Daiana Santos. O direito ao desencarceramento do acusado preso cautelarmente, caso não seja julgado no prazo razoável: análise dos critérios utilizados para

68 De todos os casos analisados, não foi possível obter a informação relativa ao julgamento da liminar em 03 (três) acórdãos: RHC 28135/PI, Quinta Turma, Rel. Min. Jorge Mussi, J. 07/12/2010; RHC 28135/PI, Quinta Turma, Rel. Min. Napoleão Nunes Maia Filho, J. 02/12/2010; RHC 25099/PR, Quinta Tuma, Rel. Min. Napoleão Nunes Maia Filho, J. 22/06/2010. 
aferição do excesso de prazo da prisão cautelar na jurisprudência dos Tribunais Superiores brasileiros. Dissertação (Mestrado em Direito Processual) - Faculdade de Direito da Universidade de São Paulo, São Paulo, 2018, p. 220.

Com relação à apreciação das liminares ${ }^{69}$ pelo Supremo Tribunal Federal, verificou-se que em 166 (cento e sessenta e seis) casos, tal Corte indeferiu-as, o que representa $80 \%$ do número total dos casos analisados, índice próximo ao do Superior Tribunal de Justiça (78\%). De outro lado, 19 (dezenove) liminares foram deferidas em tal período, o que corresponde a $9 \%$, percentagem superior ao da outra Corte aqui analisada.

GráfICO 02 - Liminares (Supremo Tribunal Federal)

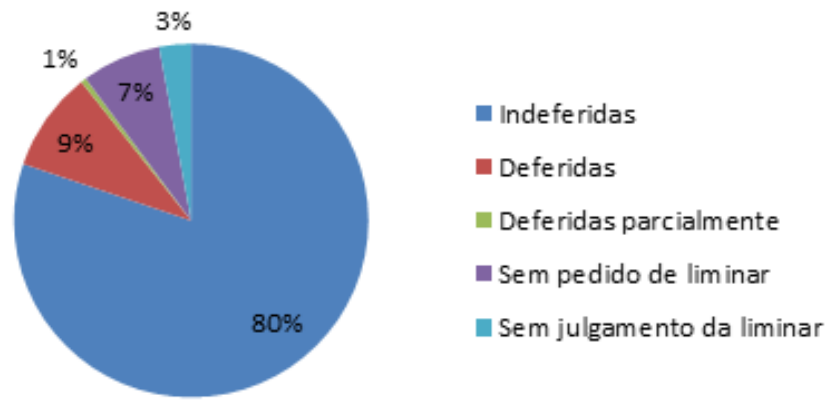

Fonte: RYU, Daiana Santos. O direito ao desencarceramento do acusado preso cautelarmente, caso não seja julgado no prazo razoável: análise dos critérios utilizados para aferição do excesso de prazo da prisão cautelar na jurisprudência dos Tribunais Superiores brasileiros. Dissertação (Mestrado em Direito Processual) - Faculdade de Direito da Universidade de São Paulo, São Paulo, 2018, p. 278.

Em regra, verificou-se que o Superior Tribunal de Justiça e o Supremo Tribunal Federal apresentaram certa resistência em deferir as liminares dos casos a eles submetidos. Dos 944 (novecentos e quarenta e quatro) acórdãos aqui analisados, apenas em 40 (quarenta) casos houve o deferimento da liminar, fração ínfima em relação ao universo aqui considerado.

${ }^{69}$ De todos os casos analisados, não foi possível obter a informação relativa à liminar em 01 (um) julgado: RHC 127757/DF, Segunda Turma, Rel. Min. Teori Zavascki, J. 02/06/2015. 


\subsection{Pareceres do Ministério Público}

Quanto à atuação do Ministério Público ${ }^{70}$ como custos legis, em 65 (sessenta e cinco) acórdãos, ou seja, em 9\% do número total de casos analisados, opinou pelo não conhecimento da ordem. Em 523 (quinhentos e vinte e três), pela denegação da ordem ${ }^{71}$, o que corresponde a $72 \%$. De outro lado, em 112 (cento e doze) acórdãos, opinou pela concessão da ordem $^{72}$, o que equivale a $15 \%$, consoante se verifica do gráfico abaixo:

\section{Gráfıco 03 - Pareceres do Ministério Público (Superior Tribunal de Justiça)}

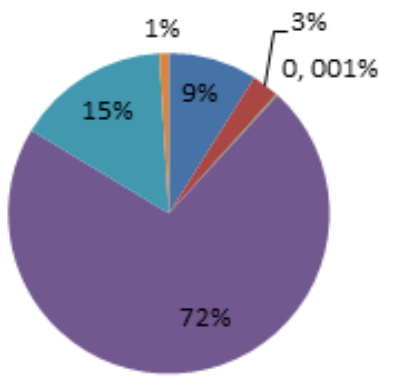

não conhecimento da ordem

n Não conhecimento ou denegação da ordem

Extinção sem resolução do mérito

Denegação

- Concessão da ordem

Fonte: RYU, Daiana Santos. O direito ao desencarceramento do acusado preso cautelarmente, caso não seja julgado no prazo razoável: análise dos critérios utilizados para aferição do excesso de prazo da prisão cautelar na jurisprudência dos Tribunais

70 Cumpre esclarecer, de início que em 09 (nove) casos não foi possível aferir o teor da manifestação do Ministério Público: RHC 68521/BA, Sexta Turma, Rel. Min. Rogerio Schietti Cruz, J. 20/10/2016; HC 350562 / CE, Sexta Turma, Rel. Min. Nefi Cordeiro, J. 07/04/2016; HC 311933/CE, Sexta Turma, Rel. Min. Nefi Cordeiro, J. 30/06/2015; HC 300328/SP, Sexta Turma, Rel. Min. Nefi Cordeiro, J. 18/06/2015; HC 281741/SP, Sexta Turma, Rel. Min. Maria Thereza Rocha de Assis Moura, J. 05/05/2015; HC 286855/SP, Quinta Turma, Rel. Min. Moura Ribeiro, J. 08/04/2014; HC 214663/MS, Quinta Turma, Rel. Min. Laurita Vaz, J. 07/05/2013; HC 65295/PE, Quinta Turma, Rel. Min. Gilson Dipp, J. 05/12/2006; HC 39481/BA, Quinta Turma, Rel. Min. Gilson Dipp, J. 12/04/2005.

${ }^{71}$ O termo "denegação da ordem" foi utilizado na tabela de forma ampla, pois engloba os casos de conhecimento parcial e denegação, conhecimento parcial e improvimento do recurso, e improvimento do recurso.

72 O termo "concessão da ordem" foi utilizado na tabela de forma ampla, pois engloba os casos de concessão da ordem, concessão de ofício, concessão parcial, conhecimento parcial e concessão da ordem, conhecimento parcial e provimento do recurso, provimento do recurso e provimento parcial do recurso. 
Superiores brasileiros. Dissertação (Mestrado em Direito Processual) - Faculdade de Direito da Universidade de São Paulo, São Paulo, 2018, p. 221.

No tocante a tal aspecto nas decisões do Supremo Tribunal Federal, de se anotar que, em mais da metade dos $\operatorname{casos}^{73}$, o Ministério Público opinou pela denegação da ordem ${ }^{74}$, totalizando o número de 136 (cento e trinta e seis) acórdãos, ou seja, 66\%. Em contrapartida, em 32 (trinta e dois) $\operatorname{casos}^{75}$, houve parecer pela concessão da ordem, o que corresponde a $16 \%$ dos casos, consoante se verifica do gráfico abaixo:

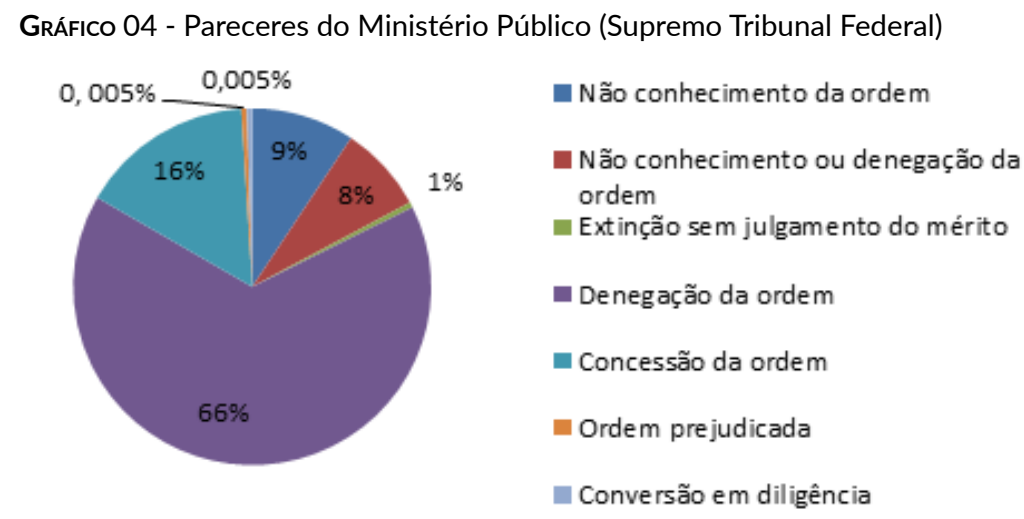

Fonte: RYU, Daiana Santos. O direito ao desencarceramento do acusado preso cautelarmente, caso não seja julgado no prazo razoável: análise dos critérios utilizados para aferição do excesso de prazo da prisão cautelar na jurisprudência dos Tribunais Superiores brasileiros. Dissertação (Mestrado em Direito Processual) - Faculdade de Direito da Universidade de São Paulo, São Paulo, 2018, p. 279.

73 Em 03 (três) casos não foi possível aferir o teor da manifestação do Ministério Público: RHC 127757/DF, Segunda Turma, Rel. Min. Teori Zavascki, J. 02/06/2015; HC 113611/RJ, Segunda Turma, Rel. Min. Cezar Peluso, J. 26/06/2012; HC 87550/ BA, Primeira Turma, Rel. Min. Menezes Direito, J. 04/03/2008.

74 O termo "denegação da ordem" foi utilizado na tabela de forma ampla, pois engloba os casos de conhecimento parcial e denegação, conhecimento parcial e improvimento do recurso, e improvimento do recurso.

75 O termo "concessão da ordem" foi utilizado na tabela de forma ampla, pois abarca os casos de concessão da ordem, concessão de ofício, concessão parcial, conhecimento parcial e concessão da ordem, conhecimento parcial e provimento do recurso, provimento do recurso e provimento parcial do recurso. 
Em linhas gerais, averiguou-se que o Ministério Público assumiu posição contrária ao desencarceramento do acusado preso cautelarmente, opinando pela manutenção da custódia cautelar na maioria dos casos aqui analisados. Em relação ao espaço amostral aqui analisado, somente em 135 (cento e trinta e cinco) casos, o Parquet ofereceu parecer pela concessão da ordem. Considerando-se o resultado supramencionado, cabe o questionamento quanto ao efetivo papel exercido pelo Ministério Público na análise do remédio constitucional aqui estudado, eis que sua atuação se aproxima mais do papel de órgão acusador do que de custos legis $^{76}$.

\title{
3.4. RESULTADO DO JULGAMENTO DOS CASOS
}

Com relação ao resultado do julgamento, cabe apontar que do número total de acórdãos, em 121 (cento e vinte e um), ou seja, em 17\%, o Superior Tribunal de Justiça decidiu pelo não conhecimento da ordem. Em 334 (trezentos e trinta e quatro), o que equivale a $45 \%$, decidiu pela denegação da ordem. Por fim, em 279 (duzentos e setenta e nove), ou seja, em $38 \%$, houve a concessão da ordem, consoante se verifica do gráfico abaixo:

Gráfıco 05 - Resultado do julgamento dos casos analisados (Superior Tribunal de Justiça)

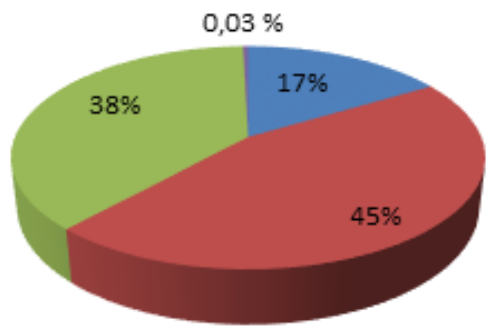

\author{
Não conhecimento da ordem \\ Denegação da ordem \\ - Concessão da ordem \\ - Ordem prejudicada
}

Fonte: RYU, Daiana Santos. O direito ao desencarceramento do acusado preso cautelarmente, caso não seja julgado no prazo razoável: análise dos critérios utilizados para

76 Tal constatação entra em conflito com o quanto já asseverado pelo Ministro Ayres Britto no julgamento do HC 102.732/2010, no qual afirmou que, em relação ao habeas corpus, o Ministério Público "se posiciona de forma imparcial, não sendo defensor de qualquer uma das partes”. Sobre o papel do Ministério Público como custos legis, ver: MAZZILLI, Hugo Nigro. A atuação do Ministério Público na segunda instância. Justitia, São Paulo, v. 67, n. 201, p. 223-228, jan./dez. 2010. 
aferição do excesso de prazo da prisão cautelar na jurisprudência dos Tribunais Superiores brasileiros. Dissertação (Mestrado em Direito Processual) - Faculdade de Direito da Universidade de São Paulo, São Paulo, 2018, p. 222.

Nesse passo, cabe apontar que dos 737 (setecentos e trinta e sete) acórdãos do banco de dados, em 682 (seiscentos e oitenta e dois), houve julgamento por unanimidade, ou seja, em $92 \%$, sendo que em 248 (duzentos e quarenta e oito) casos no sentido da concessão da ordem. Em 431 (quatrocentos e trinta e um), houve julgamento unânime pela denegação ou não conhecimento da ordem e em 03 (três) casos, considerou-se a ordem prejudicada. Ressalte-se que ao passo que em 24 (vinte e quatro) casos houve divergência entre os Ministros para a denegação ou não conhecimento da ordem, em 31 (trinta e um) casos, o julgamento para a concessão da ordem não foi unânime, consoante se vislumbra do gráfico abaixo:

GRÁFICO 06 - Placar do julgamento dos casos analisados (Superior Tribunal de Justiça)

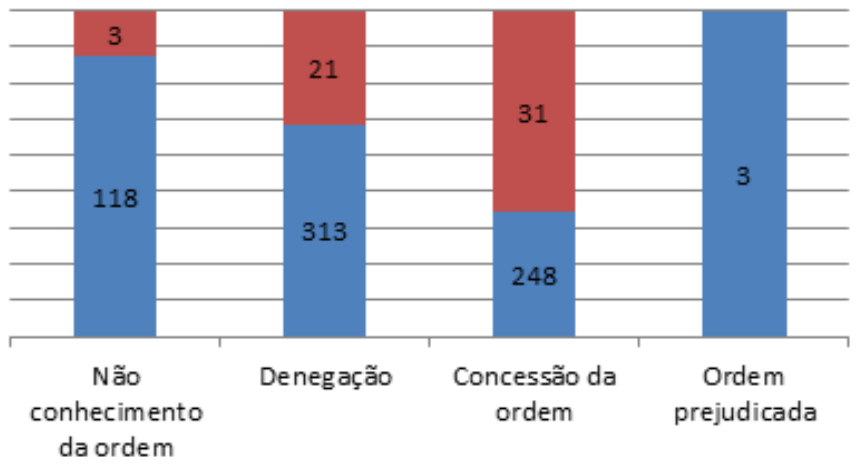

\footnotetext{
घulgamento não unânime

- Julgamento unânime
}

Fonte: RYU, Daiana Santos. O direito ao desencarceramento do acusado preso cautelarmente, caso não seja julgado no prazo razoável: análise dos critérios utilizados para aferição do excesso de prazo da prisão cautelar na jurisprudência dos Tribunais Superiores brasileiros. Dissertação (Mestrado em Direito Processual) - Faculdade de Direito da Universidade de São Paulo, São Paulo, 2018, p. 223. 
De outro giro, importante verificar a evolução das decisões proferidas pelo Superior Tribunal de Justiça ao longo do período estudado. Para tanto, reputou-se conveniente o agrupamento dos acórdãos em biênios:

GráfICO 07 - Resultado do julgamento dos casos analisados pelo Superior Tribunal de Justiça no período de 2005 a 2016

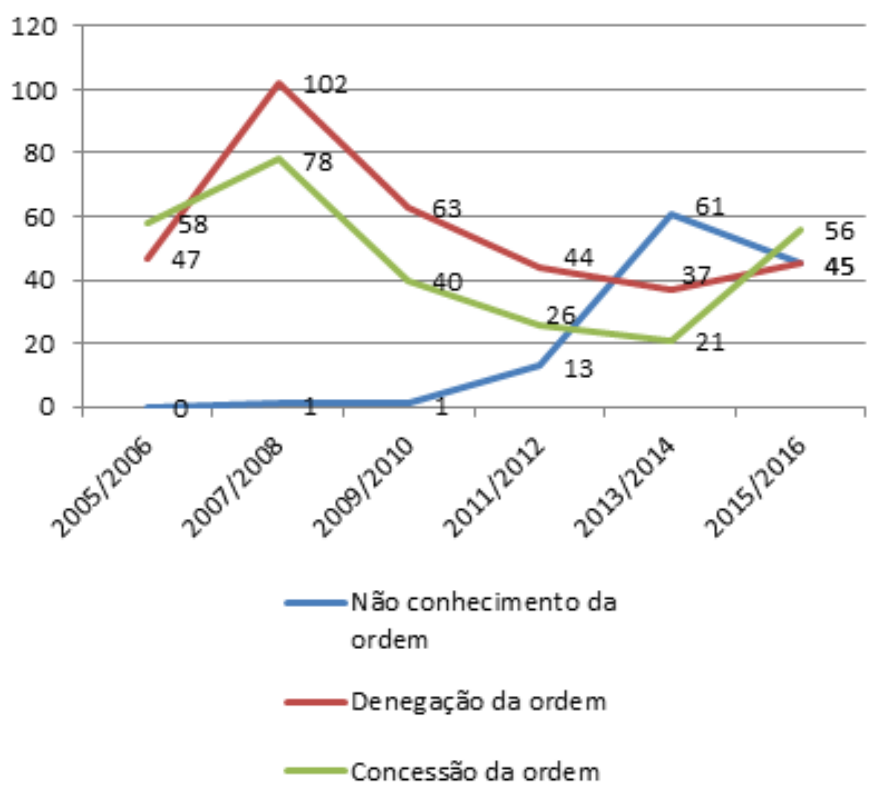

Fonte: RYU, Daiana Santos. O direito ao desencarceramento do acusado preso cautelarmente, caso não seja julgado no prazo razoável: análise dos critérios utilizados para aferição do excesso de prazo da prisão cautelar na jurisprudência dos Tribunais Superiores brasileiros. Dissertação (Mestrado em Direito Processual) - Faculdade de Direito da Universidade de São Paulo, São Paulo, 2018, p. 223.

Consoante o gráfico acima exposto, verifica-se que houve crescimento do número de concessões da ordem de habeas corpus nos últimos biênios, eis que em 2013/2014, foram concedidas 21 (vinte e uma) ordens de habeas corpus, enquanto que em 2015/2016, foram deferidos 56 (cinquenta e seis) writs. Além disso, de se destacar que ao passo que houve um decréscimo no número de denegações e concessões 
entre os biênios de 2011/2012 e 2013/2014, houve crescimento no número de acórdãos que tiveram como resultado o "não conhecimento da ordem". Tal fenômeno explica-se na alteração do entendimento dos Tribunais Superiores pátrios, principalmente a partir do ano de $2012^{77}$, que passaram a restringir o uso do habeas corpus, tendo firmado a posição no sentido da impossibilidade de impetração de tal remédio quando previsto no ordenamento jurídico brasileiro recurso próprio que vise a atacar a decisão alvo do writ $^{78}$. No entanto, apesar de não conhecerem a ordem de habeas corpus, recorrentemente, os Tribunais Superiores examinam o caso concreto a fim de verificar a ocorrência do constrangimento ilegal ${ }^{79}$.

Do número total dos julgados analisados, o Supremo Tribunal Federal decidiu pelo não conhecimento da ordem em 08 (oito) casos, ou seja, em 4\%. Em 14 (quatorze), decidiu pela extinção do julgamento sem resolução do mérito, o que equivale a 7\% dos casos. Em 111 (cento e onze) acórdãos, decidiu pela denegação da ordem ${ }^{80}$, o que equivale a $54 \%$ do total dos julgados, aproximadamente $8 \%$ a mais que o Superior Tribunal de Justiça. Em contrapartida, em 71 (setenta e um) casos, ou seja, em $34 \%$, decidiu pela concessão da ordem ${ }^{81}$, aproximadamente $4 \%$ a menos que o Superior Tribunal de Justiça, consoante se pode notar do gráfico abaixo:

77 Cf.: STF, HC 109.956/PR, Primeira Turma, Rel. Min. Marco Aurélio. J. 07/08/2012.

78 FONSECA, Tiago Abud da; MENDONÇA, Henrique Guelber de. O Supremo Tribunal Federal, a restrição ao habeas corpus e o marido traído. Boletim IBCCRIM, São Paulo, v. 21, n. 244, p. 11-12, mar. 2013.

79 Como exemplo, conferir: HC 372358/CE, Quinta Turma, Rel. Min. Joel Ilan Paciornik, J. 15/12/2016.

80 Também vale esclarecer que o termo "denegação da ordem" foi utilizado na tabela de forma ampla, pois engloba os casos de conhecimento parcial e denegação, conhecimento parcial e improvimento do recurso, e improvimento do recurso.

81 Novamente, cabe ressalvar que o termo "concessão da ordem" foi utilizado de maneira ampla, eis que o número apresentado abrange: casos de concessão da ordem, concessão de ofício, concessão parcial, conhecimento parcial e concessão da ordem, conhecimento parcial e provimento do recurso, não conhecimento, mas concessão de ofício e provimento do recurso. 
Gráfıco 08 - Resultado do julgamento dos casos analisados (Supremo Tribunal Federal)

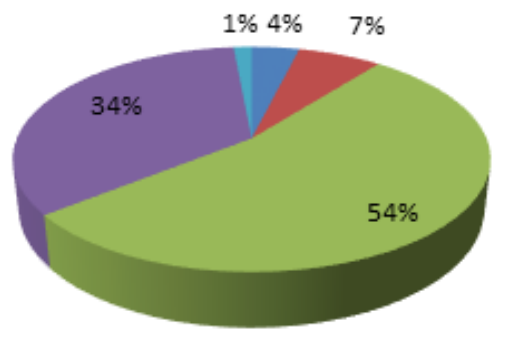

\author{
não conhecimento da ordem \\ Extinção sem resolução do \\ mérito \\ Denegação da ordem \\ E Concessão da ordem \\ Ordem prejudicada
}

Fonte: RYU, Daiana Santos. O direito ao desencarceramento do acusado preso cautelarmente, caso não seja julgado no prazo razoável: análise dos critérios utilizados para aferição do excesso de prazo da prisão cautelar na jurisprudência dos Tribunais Superiores brasileiros. Dissertação (Mestrado em Direito Processual) - Faculdade de Direito da Universidade de São Paulo, São Paulo, 2018, p. 280.

Frise-se que dos 207 (duzentos e sete) acórdãos do banco de dados, em 118 (cento e dezoito), houve julgamento por unanimidade, ou seja, em $57,9 \%$ (35\% a menos que o Superior Tribunal de Justiça), sendo que em 49 (quarenta e nove) casos, no sentido da concessão da ordem. Por outro lado, em 65 (sessenta e cinco) casos, houve julgamento unânime pela denegação da ordem, consoante se vislumbra do gráfico abaixo:

GRÁFIco 09 - Placar do julgamento dos casos analisados (Supremo Tribunal Federal)

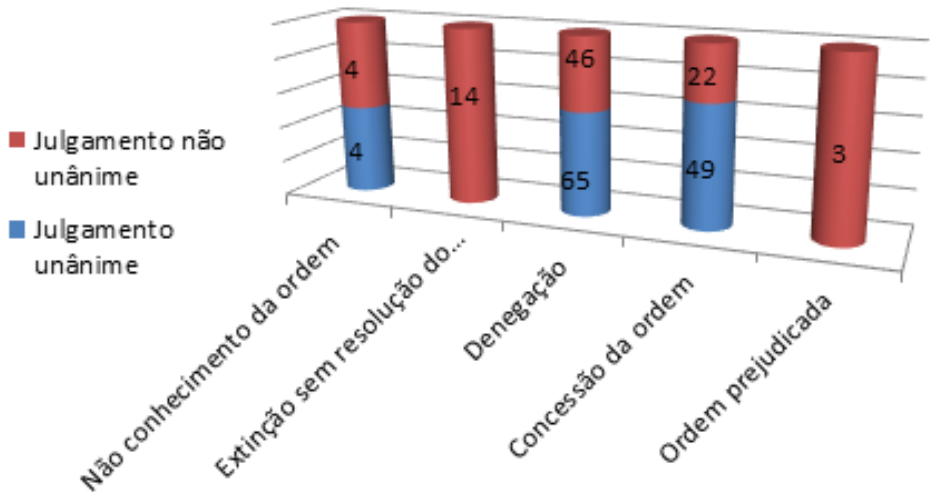

Fonte: RYU, Daiana Santos. O direito ao desencarceramento do acusado preso cautelarmente, caso não seja julgado no prazo razoável: análise dos critérios utilizados para 
aferição do excesso de prazo da prisão cautelar na jurisprudência dos Tribunais Superiores brasileiros. Dissertação (Mestrado em Direito Processual) - Faculdade de Direito da Universidade de São Paulo, São Paulo, 2018, p.280.

Por sua vez, a evolução temporal das decisões proferidas pelo Supremo Tribunal Federal ao longo do período estudado pode ser verificada no gráfico abaixo:

GráfICo 10 - Resultado do julgamento dos casos analisados pelo Supremo Tribunal Federal no período de 2005 a 2016

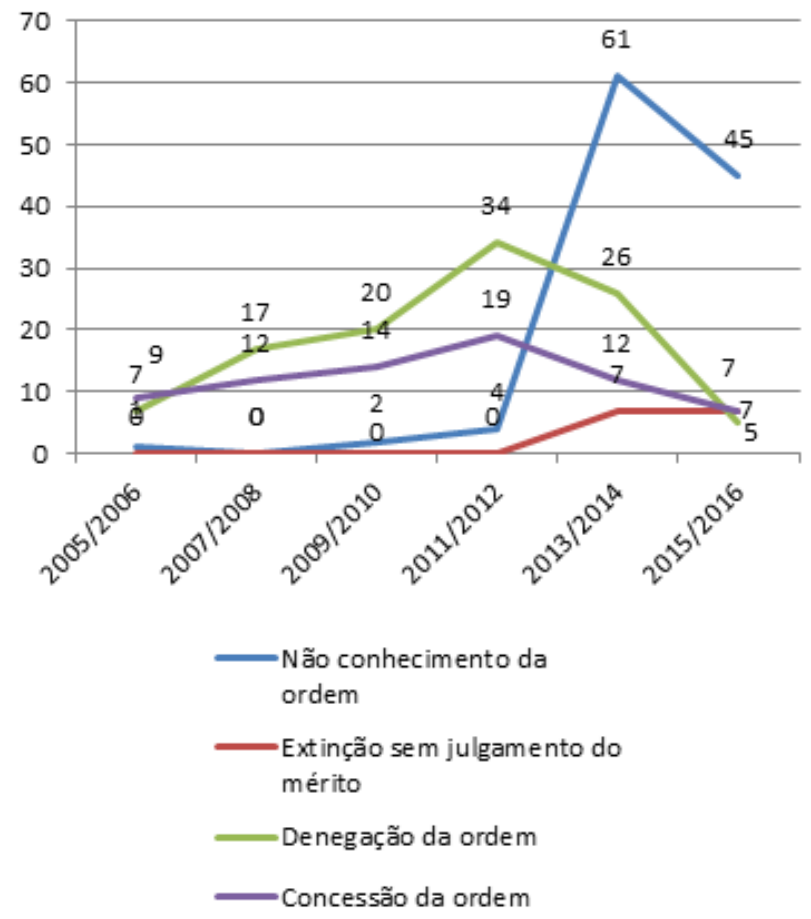

Fonte: RYU, Daiana Santos. O direito ao desencarceramento do acusado preso cautelarmente, caso não seja julgado no prazo razoável: análise dos critérios utilizados para aferição do excesso de prazo da prisão cautelar na jurisprudência dos Tribunais Superiores brasileiros. Dissertação (Mestrado em Direito Processual) - Faculdade de Direito da Universidade de São Paulo, São Paulo, 2018, p. 281. 
Consoante analisado no âmbito do Supremo Tribunal Federal, o número de casos em que a ordem foi concedida é menor do que o número de denegações e de não conhecimentos da ordem. Em suma, tanto no Supremo Tribunal Federal quanto no Superior Tribunal de Justiça, notou-se que a taxa de manutenção da prisão provisória é sempre maior do que a de concessões de liberdade.

Desta feita, constatou-se nas decisões dos Tribunais Superiores brasileiros a preferência pela prisão cautelar em detrimento da liberdade provisória e até mesmo das medidas cautelares pessoais introduzidas no Código de Processo Penal pela Lei n ${ }^{0} 12.403 / 2011$, evidenciando-se que no nosso sistema, na prática, a segregação cautelar não é tratada como medida excepcional, mas como regra ${ }^{82}$.

\subsection{DURAÇÃ̃o DA PRISÃo CAUTELAR}

Nos acórdãos analisados, quando possível, foi aferido o período da prisão cautelar do paciente, considerando-se a data da prisão e a data do julgamento do acórdão ${ }^{83}$. Dessa forma, verificou-se, por exemplo, que em 18\% das decisões, a prisão cautelar possuía duração entre 04 (quatro) e 11 (onze) meses. Além disso, em 62\% dos casos, o tempo da prisão provisória estava entre 01 (um) a 02 (dois) anos e em 18\%, a duração da prisão cautelar era de 03 (três) a 06 (seis) anos.

Frise-se, ainda, que em 04 (quatro) casos encontrados, a custódia provisória perdurava por mais de 12 anos, o que corresponde a tempo demasiadamente longo a uma medida que tem como caracteres a instrumentalidade e a provisoriedade ${ }^{84}$.

\footnotetext{
82 Sobre a excepcionalidade da prisão provisória, ver: PRADO, Geraldo. Excepcionalidade da prisão provisória. In: FERNANDES, Og (org). Medidas cautelares no processo penal, prisões e suas alternativas. São Paulo: Revista dos Tribunais, 2012, p. 121-123.

83 Em alguns casos, quando a prisão preventiva não foi decorrente da conversão da prisão em flagrante, e não tendo sido possível aferir a data do cumprimento do mandado da custódia cautelar, foi considerada a data de sua decretação.

84 TUCCI, Rogério Lauria; DELMANTO JUNIOR, Roberto. Sistematização das medidas cautelares processuais penais. Revista do Advogado, São Paulo, v. 24, n. 78 , p. 111-122, set. 2004 .
} 
GRÁFICO 11 - Duração das prisões cautelares (Superior Tribunal de Justiça)
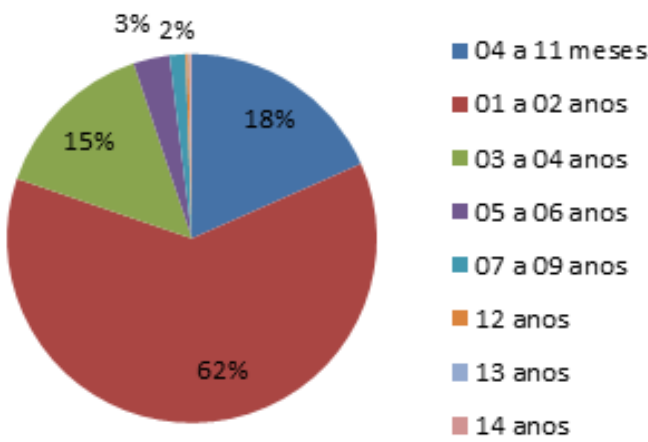

Fonte RYU, Daiana Santos. O direito ao desencarceramento do acusado preso cautelarmente, caso não seja julgado no prazo razoável: análise dos critérios utilizados para aferição do excesso de prazo da prisão cautelar na jurisprudência dos Tribunais Superiores brasileiros. Dissertação (Mestrado em Direito Processual) - Faculdade de Direito da Universidade de São Paulo, São Paulo, 2018, p. 228.

Consoante se vislumbra do gráfico acima, em nenhum caso, a prisão cautelar apresentou duração inferior a 120 (cento e vinte) dias, tendo sido encontrado acórdão em que o paciente estava preso há mais de 14 (quatorze) anos, sem que houvesse sido julgado definitivamente. Nesse caso, aliás, em razão do fato de ele possuir outras condenações, a Quinta Turma, no HC n ${ }^{\circ} 252299 / T O$, de relatoria do Ministro Marco Aurélio Bellize, em 28/05/2013, concedeu a ordem parcialmente apenas para recomendar a celeridade no julgamento da apelação interposta pela sua defesa, mantendo sua custódia cautelar.

No que tange à relação entre a concessão da liberdade e a duração das custódias provisórias, cabe apontar que em 31,6\% dos casos em que a prisão cautelar apresentava duração entre 01 (um) e 02 (dois) anos houve a soltura do paciente. Já no tocante aos casos em que o lapso temporal da prisão cautelar correspondia a 03 (três) e 04 (quatro) anos, o índice foi de 64,1\%; e nos casos em que a custódia provisória apresentava duração entre 07 (sete) e 09 (nove) anos, tal índice correspondeu a 90\%, consoante pode se vislumbrar do gráfico abaixo: 
GRÁfICo 12 - Concessão da liberdade e duração das prisões provisórias (Superior Tribunal de Justiça)

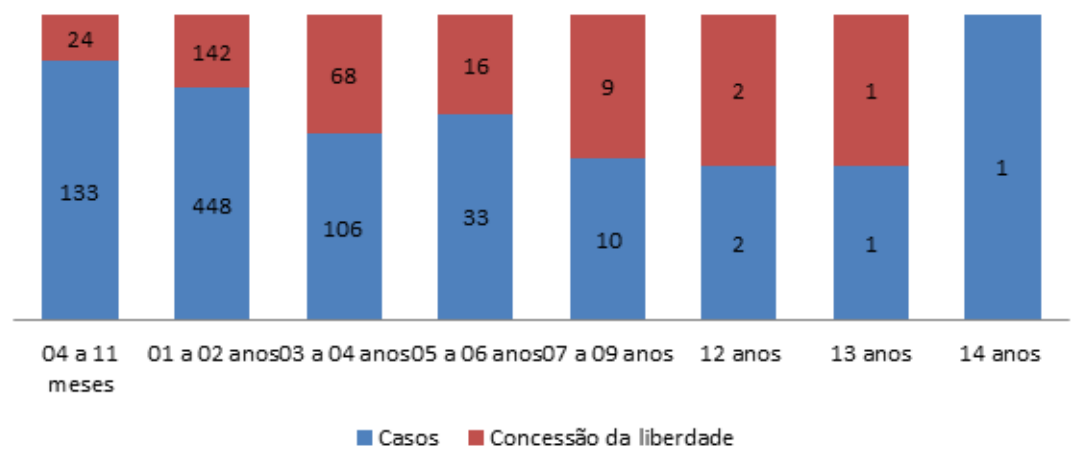

Fonte: RYU, Daiana Santos. O direito ao desencarceramento do acusado preso cautelarmente, caso não seja julgado no prazo razoável: análise dos critérios utilizados para aferição do excesso de prazo da prisão cautelar na jurisprudência dos Tribunais Superiores brasileiros. Dissertação (Mestrado em Direito Processual) - Faculdade de Direito da Universidade de São Paulo, São Paulo, 2018, p. 229.

No que tange às decisões do Supremo Tribunal Federal, verificou-se em $5 \%$ das decisões que a custódia provisória possuía duração entre 04 (quatro) e 11 (onze) meses. Além disso, em 57\% dos casos, o tempo da prisão provisória era de 01 (um) a 02 (dois) anos e em $27 \%$, a duração da prisão cautelar era de 03 (três) a 04 (quatro) anos. Em 9\%, a prisão cautelar apresentou duração entre 05 (cinco) a 06 (seis) anos.

GRÁFICo 13 - Duração das prisões cautelares (Supremo Tribunal Federal)

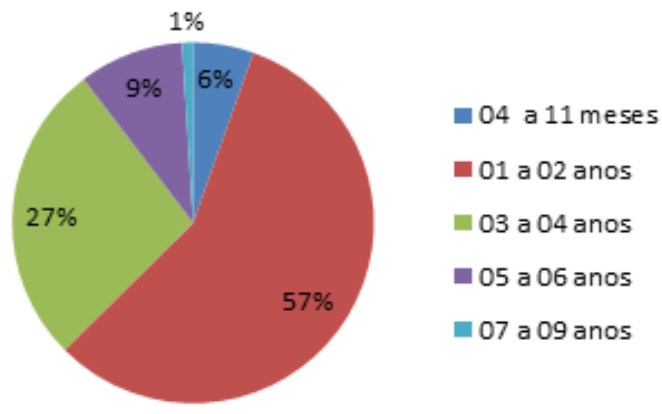

Fonte: RYU, Daiana Santos. O direito ao desencarceramento do acusado preso cautelarmente, caso não seja julgado no prazo razoável: análise dos critérios utilizados para 
aferição do excesso de prazo da prisão cautelar na jurisprudência dos Tribunais Superiores brasileiros. Dissertação (Mestrado em Direito Processual) - Faculdade de Direito da Universidade de São Paulo, São Paulo, 2018, p. 286.

No que tange à relação entre a concessão da liberdade e a duração das prisões provisórias, cabe apontar que, em $23,2 \%$ dos casos em que a custódia provisória apresentou duração entre 01 (um) e 02 (dois) anos, houve a soltura do paciente. Já quando o período da prisão cautelar correspondia a 03 (três) e 04 (quatro) anos, o índice foi de 50,9\% e nos casos em que a custódia cautelar possuía duração entre 05 (cinco) e 06 (seis) anos, o índice foi de 52,63\%. Além disso, nos dois casos em que a prisão cautelar apresentou duração entre 07 (sete) e 09 (nove) anos ${ }^{85}$, o paciente foi solto.

GRÁFICO 14 - Concessão da liberdade e duração das prisões provisórias (Supremo Tribunal Federal)

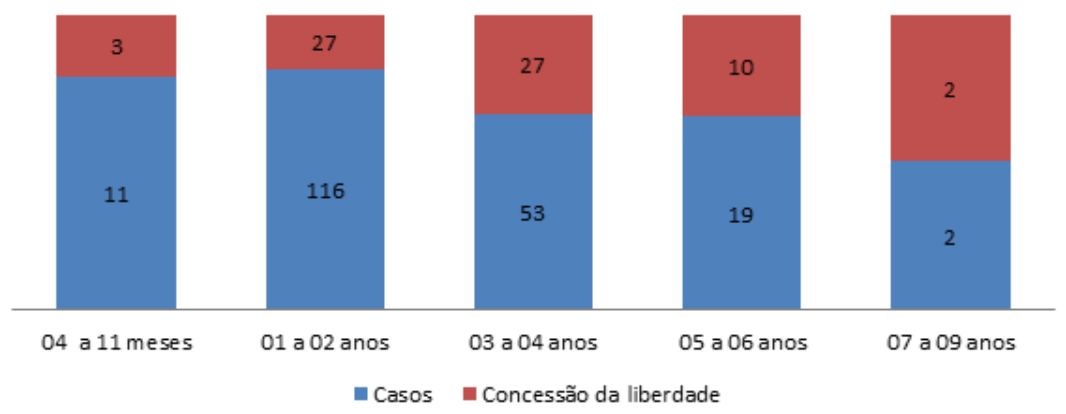

Fonte: RYU, Daiana Santos. O direito ao desencarceramento do acusado preso cautelarmente, caso não seja julgado no prazo razoável: análise dos critérios utilizados para aferição do excesso de prazo da prisão cautelar na jurisprudência dos Tribunais Superiores brasileiros. Dissertação (Mestrado em Direito Processual) - Faculdade de Direito da Universidade de São Paulo, São Paulo, 2018, p. 287.

Assim como constatado na análise dos acórdãos do Superior Tribunal de Justiça, também foi observado nas decisões do Supremo

85 HC 85011/RS, Primeira Turma, Rel. Min. Luiz Fux, J. 26/05/2015. 
Tribunal Federal que quanto maior o tempo de prisão cautelar, maior é a chance de soltura do paciente, tendo em vista o reconhecimento da irrazoabilidade do prazo da custódia provisória. No entanto, importante salientar que, em geral, notou-se duração exacerbada da prisão cautelar nos casos aqui analisados, eis que no mínimo as prisões já contavam com 120 (cento e vinte) dias. Além de violar os caracteres da provisoriedade, provisionalidade e da instrumentalidade das medidas cautelares ${ }^{86}$, a longa duração da prisão intensifica os efeitos deletérios que recaem sobre o indivíduo submetido à persecução penal. Com a indefinição do prazo da prisão preventiva, intensificam-se sobre o acusado o sofrimento psicológico, a angústia e principalmente a estigmatização perante a sociedade ${ }^{87}$.

\subsection{TIPOS PENAIS}

No espaço amostral aqui analisado, notou-se que os processos com prisão cautelar apuram a prática de uma pluralidade de crimes, que vão desde delitos contra o patrimônio até delitos contra a Administração Pública. Os três crimes que mais incidiram nos casos em estudo foram roubo, homicídio e tráfico de drogas, consoante se pode averiguar da tabela abaixo ${ }^{88}$ :

TABela 01 - Tipos penais (Superior Tribunal de Justiça)

\begin{tabular}{c|c}
\hline CRIME & $\begin{array}{c}\text { NÚMERO DE CASOS } \\
\text { ANALISADOS }\end{array}$ \\
\hline $\begin{array}{c}\text { Tráfico de drogas, associação para o tráfico e } \\
\text { outros tipificados na Lei no } 11.343 / 2006\end{array}$ & 251 \\
\hline Homicídio & 242 \\
\hline
\end{tabular}

86 TUCCI, Rogério Lauria; DELMANTO JUNIOR, Roberto. Sistematização das medidas cautelares processuais penais. Revista do Advogado, São Paulo, v. 24, n. 78, p. 111-122, set. 2004, p. 118.

87 FERRAJOLI, Luigi. Direito e razão: teoria do garantismo penal. Tradução Ana Paula Zomer et alii. São Paulo: Revista dos Tribunais, 2002, p. 322.

${ }_{88}$ Na tabela, os números inseridos equivalem ao número de casos em que tais delitos estavam presentes de forma individual ou conjunta a outro(s) crime(s). 


\begin{tabular}{c|c}
\hline CRIME & $\begin{array}{c}\text { NÚMERO DE CASOS } \\
\text { ANALISADOS }\end{array}$ \\
\hline Roubo & 133 \\
\hline $\begin{array}{c}\text { Porte ilegal de arma de fogo de uso restrito e } \\
\text { outros crimes previstos na Lei n }{ }^{\circ} \text { 10.826/2003 }\end{array}$ & 32 \\
\hline Furto & 28 \\
\hline Receptação & 19 \\
\hline Estupro e outros crimes contra a liberdade sexual & 14 \\
\hline Latrocínio & 13 \\
\hline Estelionato & 12 \\
\hline $\begin{array}{c}\text { Extorsão mediante sequestro } \\
\text { Corrumes contra a fé pública } \\
\text { contra a Administração Pública }\end{array}$ & 11 \\
\hline Tortura & 6 \\
\hline (uso de documento falso e moeda falsa) & 13 \\
\hline
\end{tabular}

Fonte: RYU, Daiana Santos. O direito ao desencarceramento do acusado preso cautelarmente, caso não seja julgado no prazo razoável: análise dos critérios utilizados para aferição do excesso de prazo da prisão cautelar na jurisprudência dos Tribunais Superiores brasileiros. Dissertação (Mestrado em Direito Processual) - Faculdade de Direito da Universidade de São Paulo, São Paulo, 2018, p. 230.

Quanto ao tempo de duração da prisão cautelar em relação aos principais delitos, notou-se que os casos que envolviam o delito de homicídio apresentaram, em média, a maior duração das prisões cautelares.

Assim, de se ressaltar que em aproximadamente $40 \%$ dos casos relacionados ao crime de homicídio, a prisão provisória apresentava duração entre 02 (dois) e 03 (três) anos, e em 14,04\%, 04 (quatro) a 05 (cinco) anos, no momento em que o habeas corpus ou recurso ordinário em habeas corpus foi julgado pelo Superior Tribunal de Justiça. De outro lado, no que tange ao delito de tráfico de drogas, em $22 \%$ dos casos, a prisão cautelar apresentava duração entre 02 (dois) e 03 (três) anos e em 5\% dos casos, 04 (quatro) a 05 (cinco) anos. Nos casos envolvendo 
o delito de roubo, em 23\%, a custódia provisória apresentava duração de 02 (dois) a 03 (três) anos e em 4\%, de 04 (quatro) a 05 (cinco) anos.

GRÁFICo 15 - Tipos penais e duração da prisão cautelar (Superior Tribunal de Justiça)

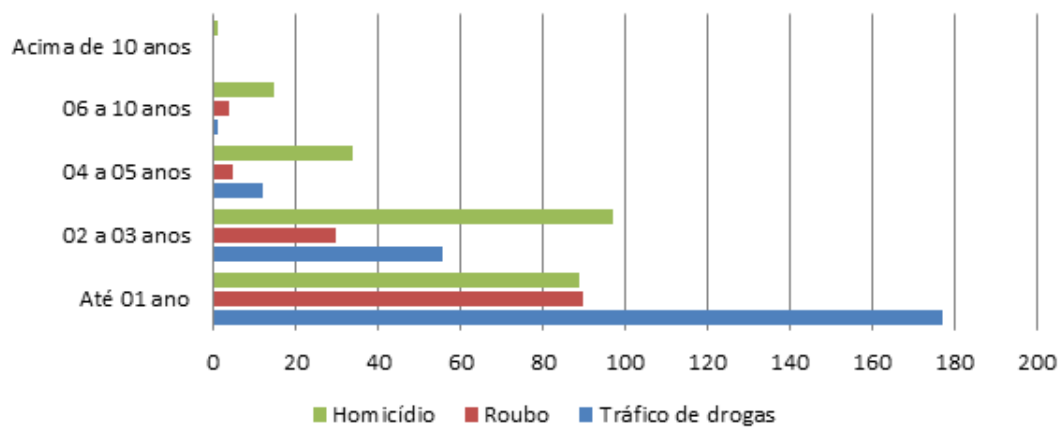

Fonte: RYU, Daiana Santos. O direito ao desencarceramento do acusado preso cautelarmente, caso não seja julgado no prazo razoável: análise dos critérios utilizados para aferição do excesso de prazo da prisão cautelar na jurisprudência dos Tribunais Superiores brasileiros. Dissertação (Mestrado em Direito Processual) - Faculdade de Direito da Universidade de São Paulo, São Paulo, 2018, p. 231.

Com relação aos julgados analisados do Supremo Tribunal Federal, também se observou que os três crimes mais recorrentes foram homicídio, tráfico de drogas e roubo, conforme se pode averiguar na tabela abaixo ${ }^{89}$ :

TABELA 02 - Tipos penais (Supremo Tribunal Federal)

\begin{tabular}{c|c}
\hline CRIME & $\begin{array}{c}\text { NÚMERO DE CASOS } \\
\text { ANALISADOS }\end{array}$ \\
\hline Homicídio & 74 \\
\hline $\begin{array}{c}\text { Tráfico de drogas, associação para o tráfico e } \\
\text { outros tipificados na Lei no } 11.343 / 2006\end{array}$ \\
\hline
\end{tabular}

89 Na tabela, os números inseridos equivalem ao número de casos em que tais delitos estavam presentes de forma individual ou conjunta a outro(s) crime(s). 


\begin{tabular}{c|c}
\hline CRIME & $\begin{array}{c}\text { NÚMERO DE CASOS } \\
\text { ANALISADOS }\end{array}$ \\
\hline Roubo & 19 \\
\hline $\begin{array}{c}\text { Porte ilegal de arma de fogo de uso } \\
\text { restrito e outros crimes previstos } \\
\text { na Lei no } 10.826 / 2003\end{array}$ & 11 \\
\hline Furto & 10 \\
\hline Estelionato & 10 \\
\hline $\begin{array}{c}\text { Corrupção e outros crimes } \\
\text { contra a Administração Pública }\end{array}$ & 8 \\
\hline Latrocínio & 7 \\
\hline a liberdade sexual & 7 \\
\hline Receptação & 5 \\
\hline Trupro e outros crimes contra & 5 \\
\hline Crimes contra a fé pública & 2 \\
\hline Tortura & 17 \\
\hline
\end{tabular}

Fonte: RYU, Daiana Santos. O direito ao desencarceramento do acusado preso cautelarmente, caso não seja julgado no prazo razoável: análise dos critérios utilizados para aferição do excesso de prazo da prisão cautelar na jurisprudência dos Tribunais Superiores brasileiros. Dissertação (Mestrado em Direito Processual) - Faculdade de Direito da Universidade de São Paulo, São Paulo, 2018, p. 288.

Tal como verificado na análise dos acórdãos do Superior Tribunal de Justiça, quanto ao tempo de duração da prisão cautelar em relação aos principais delitos, notou-se que os casos que envolviam o delito de homicídio apresentaram, em média, a maior duração das prisões cautelares. Em aproximadamente $43,83 \%$ dos casos relacionados ao crime de homicídio, a prisão provisória apresentava duração entre 02 (dois) e 03 (três) anos e em 26,03\%, 04 (quatro) a 05 (cinco) anos, no momento em que o habeas corpus ou recurso ordinário em habeas corpus foi julgado pelo Supremo Tribunal Federal. De outro lado, no que tange ao delito de tráfico de drogas, em $49 \%$ dos casos, a prisão 
cautelar apresentava duração entre 02 (dois) e 03 (três) anos e em 12,3\% dos casos, 04 (quatro) a 05 (cinco) anos. Já com relação aos casos envolvendo o delito de roubo, em $42,10 \%$ dos casos, a custódia provisória apresentava duração de 02 (dois) a 03 (três) anos e em 10,5 $\%$ dos casos, de 04 (quatro) a 05 (cinco) anos.

GRÁFICo 16 - Tipos penais e duração da prisão cautelar (Supremo Tribunal Federal)

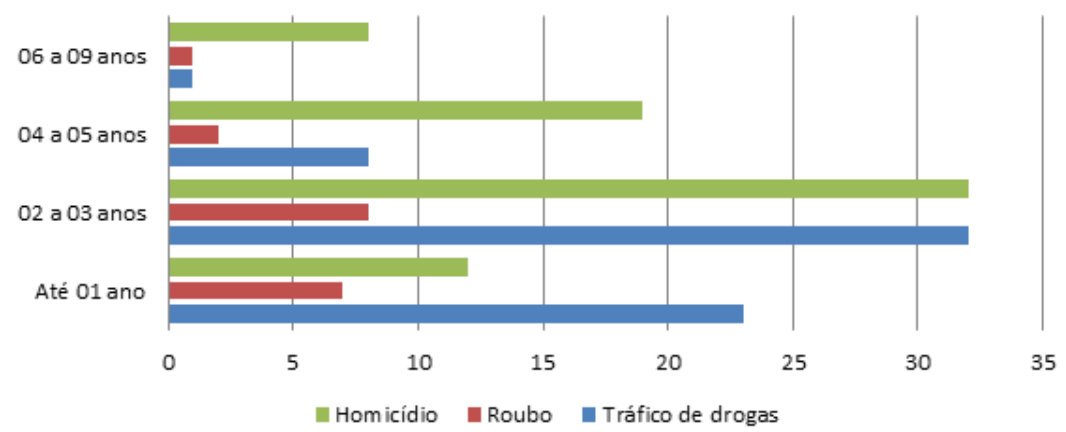

Fonte: RYU, Daiana Santos. O direito ao desencarceramento do acusado preso cautelarmente, caso não seja julgado no prazo razoável: análise dos critérios utilizados para aferição do excesso de prazo da prisão cautelar na jurisprudência dos Tribunais Superiores brasileiros. Dissertação (Mestrado em Direito Processual) - Faculdade de Direito da Universidade de São Paulo, São Paulo, 2018, p. 289.

\subsection{CRITÉRIOS UtILIZAdos PARA AFERIÇÃo da RAZOABILIDADE DO PRAZO}

Considerando-se que o ordenamento jurídico brasileiro não estabelece prazo máximo para duração do processo penal bem como para prisão preventiva, tendo adotado a doutrina do "não-prazo", sob influência das Cortes Europeia e Interamericana de Direitos Humanos, os Tribunais Superiores pátrios têm utilizado os critérios da complexidade da causa, do comportamento da parte e da conduta das autoridades judiciárias para aferição da razoabilidade do prazo da prisão cautelar.

No que tange às decisões proferidas pelo Superior Tribunal de Justiça, verificou-se que o critério do comportamento da parte foi 
utilizado em 173 (cento e setenta e três) decisões, ou seja, em 23,4\% dos casos analisados e o critério da conduta das autoridades judiciárias em 260 (duzentas e sessenta) decisões, o que equivale a $35,2 \%$ dos casos. De outro lado, o critério mais utilizado pelo Superior Tribunal de Justiça, no período de 30/12/2004 a 30/12/2016, foi o da complexidade da causa, tendo sido mencionado em 351 (trezentos e cinquenta e um) julgados, o que equivale a 47,6\% dos casos analisados, conforme se verifica do gráfico abaixo:

GráfICo 17 - Critérios utilizados nas decisões do Superior Tribunal de Justiça

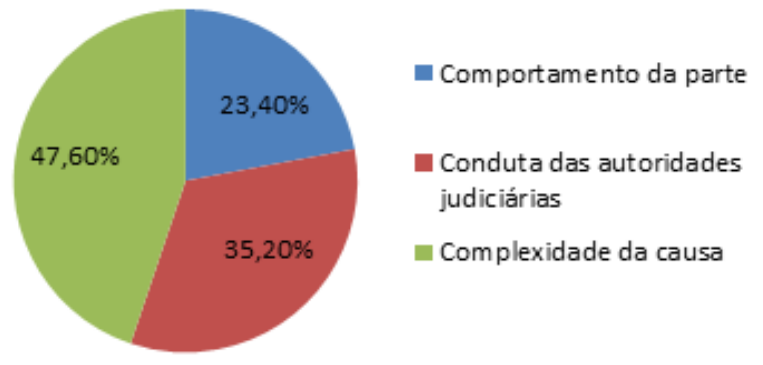

Fonte: RYU, Daiana Santos. O direito ao desencarceramento do acusado preso cautelarmente, caso não seja julgado no prazo razoável: análise dos critérios utilizados para aferição do excesso de prazo da prisão cautelar na jurisprudência dos Tribunais Superiores brasileiros. Dissertação (Mestrado em Direito Processual) - Faculdade de Direito da Universidade de São Paulo, São Paulo, 2018, p. 234.

Com relação aos julgados analisados do Supremo Tribunal Federal, constatou-se que o critério do comportamento da parte foi utilizado em 59 (cinquenta e nove) decisões, ou seja, em $28,5 \%$ dos casos analisados e o critério da conduta das autoridades judiciárias, em 66 (sessenta e seis), o que equivale a $31,8 \%$. De outro lado, assim como averiguado na pesquisa relativa ao Superior Tribunal de Justiça, o critério mais utilizado pelo Supremo Tribunal Federal, no período de 30/12/2004 a 30/12/2016, foi o da complexidade da causa, tendo sido mencionado em 119 (cento e dezenove) acórdãos, o que equivale a 57,4\% dos casos analisados, conforme se afere do gráfico abaixo: 
Gráfıco 18 - Critério utilizado nas decisões do Supremo Tribunal Federal

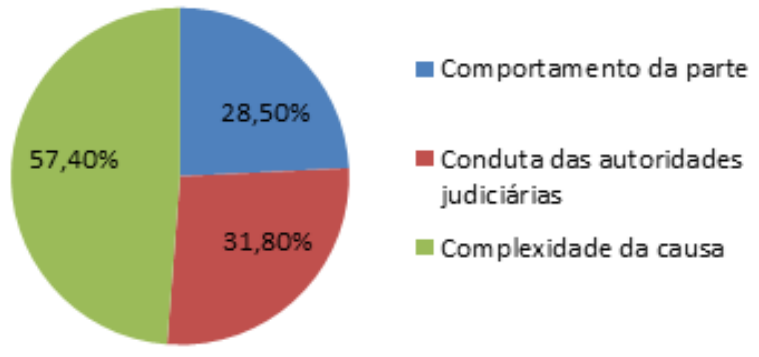

Fonte: RYU, Daiana Santos. O direito ao desencarceramento do acusado preso cautelarmente, caso não seja julgado no prazo razoável: análise dos critérios utilizados para aferição do excesso de prazo da prisão cautelar na jurisprudência dos Tribunais Superiores brasileiros. Dissertação (Mestrado em Direito Processual) - Faculdade de Direito da Universidade de São Paulo, São Paulo, 2018, p. 291.

Consoante verificado acima, vislumbra-se que tanto o Superior Tribunal de Justiça como o Supremo Tribunal Federal têm, de fato, lançado mão da teoria dos três critérios para aferição da razoabilidade do prazo da prisão cautelar a fim de diminuir a vagueza e a indeterminabilidade do conceito de "prazo razoável". Assim, grande parcela das decisões proferidas pelos Tribunais Superiores pátrios em sede de habeas corpus cujo pedido é a verificação de constrangimento ilegal por excesso de prazo da prisão cautelar, são aplicados os critérios: da complexidade da causa, visando-se averiguar se o processo detém alguma nota de complexidade que justifique determinada duração da custódia provisória, como multiplicidade de crimes ou acusados; do comportamento da parte, com o escopo de aferir eventual comportamento protelatório da parte e conduta das autoridades judiciárias, por meio do qual se verifica eventual morosidade por culpa do Estado na administração da Justiça.

\section{Algumas notas sobre a aferição da razoabilidade do prazo DA PRISÃo CAUTELAR PELOS TRIBUNAIS SUPERIORES PÁTRIOS}

Conforme já debatido na doutrina processual penal ${ }^{90}$, a falta de previsão em lei de prazo máximo para duração do processo penal e da

90 Cf. GIACOMOLLI, Nereu José. O devido processo penal: abordagem conforme a Constituição Federal e o Pacto de São José da Costa Rica. 2. ed. São Paulo: 
prisão preventiva além de acarretar insegurança jurídica ao acusado, principalmente àquele preso provisoriamente, oferece ampla margem de discricionariedade ao órgão julgador, o qual diante de um termo vago tal qual o previsto no artigo $5^{\circ}$, inciso LXXVIII, da Constituição da República, acaba lançando mão de critérios igualmente vagos para justificar a longa duração de uma custódia provisória.

Ressalte-se que em nenhum dos casos analisados, tanto em relação ao Superior Tribunal de Justiça como em relação ao Supremo Tribunal Federal, a prisão cautelar apresentou duração inferior a 120 (cento e vinte) dias. Além disso, em mais da metade dos julgados (62\% dos casos do Superior Tribunal de Justiça e 57\% do Supremo Tribunal Federal), a custódia provisória já durava entre um e dois anos, tempo excessivamente longo se considerar que a prisão cautelar tem como caracteres principais a instrumentalidade e a provisoriedade ${ }^{91}$.

Com efeito, verificou-se ao longo da pesquisa que os critérios utilizados pelos Tribunais Superiores pátrios são adotados de maneira aleatória, não havendo, na maioria das vezes, fundamentação idônea em relação ao preenchimento do conteúdo de cada critério. Averiguou-se, de maneira geral, que não há preocupação por parte do órgão julgador em aplicar o critério escolhido por meio da análise de todas as circunstâncias do caso concreto, individuando-se o motivo da demora que determinado elemento provoca ao andamento do processo e, por consequência, à duração da prisão cautelar.

Na maioria dos casos, portanto, notou-se que o critério da complexidade da causa, do comportamento da parte e da conduta das autoridades judiciárias são fundamentados de maneira rasa, através da mera citação de elementos/fatores para justificá-los. Entre os casos analisados,

Atlas, 2015, p. 344; BADARÓ, Gustavo Henrique; LOPES JÚNIOR, Aury. Direito ao processo penal no prazo razoável. Rio de Janeiro: Lumen Juris, 2006, p. 84; PASTOR, Daniel R. El plazo razonable en el proceso del Estado de Derecho: una investigación acerca del problema de la excesiva duración del proceso penal y sus posibles soluciones. Buenos Aires: Ad-Hoc, Konrad - Adenauer Stiftung, 2002, p. 406-410.

91 TUCCI, Rogério Lauria; DELMANTO JUNIOR, Roberto. Sistematização das medidas cautelares processuais penais. Revista do Advogado, São Paulo, v. 24, n. 78 , p. 111-122, set. 2004 . 
a título de exemplo, no $\mathrm{HC}^{\circ} 97900 / \mathrm{SP}$, julgado pela Primeira Turma do Supremo Tribunal Federal em 16/03/2010, não houve sequer a menção ao número de réus que justificava a complexidade da causa, limitandose a fundamentá-lo no "elevado número de corréus", consoante trecho abaixo transcrito:

Aqui, estamos diante dos crimes de tráfico ilícito de entorpecente, associação para o tráfico, porte ilegal de armas, nos quais há presente complexidade, como está no parecer do Ministério Público do feito, elevado número de corréus e daí, então, uma maior dificuldade para o encerramento de instrução, pelo que o Ministro Relator acabou de mencionar, já estão, inclusive, os autos conclusos para sentença. (HC 97900/SP, Primeira Turma, Rel. Min. Dias Toffoli, J. 16/03/2010 - grifos nossos)

Por sua vez, o critério da conduta das autoridades judiciárias foi justificado tão somente na diligência da autoridade judiciária em conduzir o processo ou na ausência de desídia de tal órgão estatal, não havendo aprofundamento dos motivos que ensejaram tal conclusão por parte do tribunal. Nessa esteira, no HC n ${ }^{\circ} 94486 /$ SP, julgado pela Primeira Turma do Superior Tribunal de Justiça em 14/10/2008, apenas justificou-se a conduta da autoridade judiciária em suposta ausência de culpa na demora do processo:

Com efeito, não há nos autos comprovação de que eventual demora estaria ocorrendo por inércia do Poder Judiciário. Anote-se que o prazo transcorrido entre a prisão preventiva e a presente data, por si só, não induz à conclusão de que esteja ocorrendo o excesso, mormente se considerada a complexidade do feito, que envolve grande número de réus (mais de 50), bem como a expedição de cartas precatórias para diversas unidades federativas (...) Não há, assim, nenhum indício de que a ação penal tenha ficado paralisada por culpa do Poder Judiciário (...) (HC no 94486/SP, Primeira Turma, Rel.: Menezes de Direito, J. 14/10/2008 - grifos nossos)

Com relação ao comportamento da parte, além da superficialidade da fundamentação da decisão acima mencionada, impende salientar que em vários acórdãos, tanto do Superior Tribunal de Justiça como do 
Supremo Tribunal Federal, tal critério foi utilizado para imputar a culpa da demora da marcha processual ao acusado ou à sua defesa, em razão do exercício de um direito decorrente da garantia da ampla defesa, tal como a interposição de recursos. Nesse sentido é o trecho do HC $\mathrm{n}^{\mathrm{o}}$ 305284/AL, julgado pela Quinta Turma do Superior Tribunal de Justiça em 05/02/2015, conforme excerto abaixo:

Da leitura dos autos, tem-se que há justificativa plausível para o retardo no julgamento do paciente, eis que de acordo com as informações do juiz de primeira instância, a defesa requereu a expedição de carta precatória, além de se valer do recurso de embargos de declaração e, depois, recurso em sentido estrito. (HC 305284/AL, Quinta Turma, Rel. Felix Fischer, J. 05/02/2015 - grifos nossos)

Por meio dos exemplos acima expostos, resta evidente a complicada situação do ordenamento jurídico brasileiro em razão da ausência de prazos fixos para regulamentar a duração do processo penal e da prisão cautelar. De fato, as decisões são fundamentadas de maneira bem sucinta, impedindo-se que se conheça de maneira mais profunda os motivos que deram ensejo à aplicação de determinado critério, deixando-se nas mãos do órgão julgador a determinação da razoabilidade ou irrazoabilidade do prazo da prisão cautelar.

\section{Considerações Finais}

Consoante o Levantamento Nacional de Informações Penitenciárias - Infopen/2016, publicado pelo Departamento Penitenciário Nacional ${ }^{92}$, em junho de 2016, do número total de 726.712 (setecentos e vinte e seis mil e setecentos e doze) pessoas presas, 292.450 (duzentas e

92 BRASIL. DEPARTAMENTO PENITENCIÁRIO NACIONAL (MINISTÉRIO DA JUSTIÇA). Levantamento Nacional de Informações Penitenciárias - Infopen, Junho/2016. Brasília, 2017, p. 14. Disponível em: <http://justica.gov. $\mathrm{br} /$ sua-seguranca/seguranca-publica/analise-e-pesquisa/download/outras publicacoes/pagina-3/24levantamento_nacional_info_penitenciarias.pdf/ view>. Acesso em: $22 \mathrm{dez} .2017$. 
noventa e duas mil e quatrocentos e cinquenta) correspondiam a presos provisórios, número consideravelmente elevado. Ao longo da pesquisa apresentada no presente artigo, demonstrou-se que há, de fato, tendência dos Tribunais Superiores pátrios em manter as prisões cautelares que são a eles submetidas para análise, colaborando-se com a mantença dos dados acima mencionados.

Notou-se que mesmo se exacerbada a duração da prisão cautelar, na maioria dos casos, as liminares são indeferidas e o resultado do julgamento dos acórdãos quase sempre se destinam à denegação do writ ou ao não conhecimento da ordem, impedindo-se a soltura de um número considerável de presos provisórios, que cometeram, em especial, os delitos de homicídio, roubo e tráfico de drogas. Além disso, notou-se que grande parcela dos pareceres do Ministério Público, como custos legis, são no sentido de denegação ou não conhecimento da ordem, influenciando os Tribunais Superiores pátrios na manutenção de prisões provisórias por tempo indefinido.

Outra importante constatação realizada na presente pesquisa corresponde ao fato de que tal como em âmbito internacional, tanto o Supremo Tribunal Federal como o Superior Tribunal de Justiça lançam mão de critérios para aferição da razoabilidade do prazo da prisão cautelar. Assim, verificou-se que para determinar se a delonga da custódia provisória é razoável ou não, os Tribunais Superiores pátrios têm aplicado os critérios da complexidade da causa, do comportamento da parte e da conduta das autoridades judiciárias.

Embora a aplicação de tais critérios tenha como escopo a diminuição da vagueza e indeterminabilidade do conceito de prazo razoável, não resolvem totalmente o problema em questão. Isto porque, segundo se averiguou nos resultados obtidos na pesquisa apresentada, tais critérios são tão vagos quanto o teor do artigo $5^{\circ}$, inciso LXXVIII, da Constituição da República, permitindo-se ampla margem de discricionariedade ao órgão julgador na aferição da razoabilidade do prazo. Em síntese, cabe ressaltar que os Tribunais Superiores pátrios têm aplicado os critérios da complexidade da causa, do comportamento da parte e da conduta das autoridades judiciárias, de maneira aleatória, não apresentando fundamentação idônea baseada em análise percuciente das circunstâncias do caso concreto. 
Em suma, verificou-se que há tendência nos Tribunais Superiores pátrios em manter prisões provisórias longas por meio de argumentação genérica, pautada em elementos vagos, o que corrobora certamente com a existência do alto índice de prisões cautelares nos estabelecimentos prisionais brasileiros.

\section{REFERÊNCIAS}

BADARÓ, Gustavo Henrique. Processo penal. 5. ed. São Paulo: Revista dos Tribunais, 2017.

BADARÓ, Gustavo Henrique; LOPES JÚNIOR, Aury. Direito ao processo penal no prazo razoável. Rio de Janeiro: Lumen Juris, 2006.

BARRETO, Ireneu Cabral. A Convenção Europeia de Direitos do Homem - anotada. 5. ed. Coimbra: Almedina, 2015 (E-book).

BARROS, Flaviane Magalhães. O tempo devido do processo penal e a influência das decisões da CADH no Brasil. MALAN, Diogo; PRADO, Geraldo (coord.). Processo penal e direitos humanos. Rio de Janeiro: Lumen Juris, 2012, p. 59-75.

BARTOLE, Sergio; CONFORTI, Benedetto; RAIMONDI, Guido. Commentario alla Convenzione Europea per la tutela dei diritti dell'uomo e delle libertà fondamentali. Milano: CEDAM, 2001.

BÁRTOLI, Márcio Orlando. O critério da razoabilidade (jurisprudência comentada). Revista Brasileira de Ciências Criminais, São Paulo, v. 1, n. 3, p. 184-187, jul./set. 1993.

BEDAQUE, José Roberto dos Santos. Tutela cautelar e tutela antecipada: tutelas sumárias e de urgência (tentativa de sistematização). 5. ed. São Paulo: Malheiros, 2009.

CARBONELL, José Carlos Remotti. La Corte Interamericana de Derechos Humanos. Estructura, funcionamiento y jurisprudencia. Barcelona: Instituto Europeo de Derecho, 2013.

CARNELUTTI, Francesco. As misérias do processo penal. Tradução Carlos Eduardo Trevelin Millan. São Paulo: Pillares, 2009.

CHIAVARIO, Mario. Procedure penali d'europa: Belgio, Francia, Germania, Inghilterra, Italia. Milano: CEDAM, 2001.

CHIAVARIO, Mario. Processo e garanzie della persona: le singole garanzie. 3. ed. Milano: Giuffrè, 1984. v. 2. 
BRASIL. DEPARTAMENTO PENITENCIÁRIO NACIONAL (MINISTÉRIO DA JUSTIÇA). Levantamento Nacional de Informações Penitenciárias - Infopen, Junho/2016. Brasília, 2017, p. 14. Disponível em: <http://justica.gov.br/sua-seguranca/seguranca-publica/analise-e-pesquisa/download/outras_publicacoes/ pagina-3/24levantamento_nacional_info_penitenciarias.pdf/view>. Acesso em: 22 dez. 2017.

FERNANDES, Antonio Scarance. Processo penal constitucional. 4. ed. São Paulo: Revista dos Tribunais, 2005.

FERNANDEZ-VIAGAS BARTOLOME, Placido. El derecho a un proceso sin dilaciones indebidas. Madrid: Civitas, 1994.

FERRAJOLI, Luigi. Direito e razão: teoria do garantismo penal. Tradução Ana Paula Zomer et alii. São Paulo: Revista dos Tribunais, 2002.

FONSECA, Tiago Abud da; MENDONÇA, Henrique Guelber de. O Supremo Tribunal Federal, a restrição ao habeas corpus e o marido traído. Boletim IBCCRIM, São Paulo, v. 21, n. 244, p. 11-12, mar. 2013.

FRANCO, Alberto Silva. Prazo razoável e o estado democrático de direito. Boletim IBCCRIM, São Paulo, v. 13, n. 152, p. 6-7, jul. 2005.

GARCÍA- LÚBEN BARTHE, Paloma. El derecho a un proceso en un plazo razonable en el ámbito europeo. Análisis e interpretación del artículo 6.1 del Convenio Europeo de Derechos Humanos. ARMENTA DEU, Teresa; CALDERÓN CUADRADO, María Pía; OLIVA SANTOS, Andrés de la (Coord.). Garantías fundamentales del proceso penal en el espacio judicial europeo. Madrid: Colex, 2007, p. 273-285.

GRINOVER, Ada Pellegrini; FERNANDES, Antonio Scarance; GOMES FILHO, Antonio Magalhães. As nulidades no processo penal. 10. ed. São Paulo: Revista dos Tribunais, 2008.

GIACOMOLLI, Nereu José. Prisão, liberdade e as cautelares alternativas ao cárcere. São Paulo: Marcial Pons, 2013.

GIACOMOLLI, Nereu José. O devido processo penal: abordagem conforme a Constituição Federal e o Pacto de São José da Costa Rica. 2. ed. São Paulo: Atlas, 2015.

KOEHLER, Frederico Augusto Leopoldino. A razoável duração do processo. 2. ed. Salvador: Juspodivum, 2013. 
LACAVA, Thaís Aroca Datcho. A garantia da duração razoável da persecução penal. Dissertação (Mestrado em Direito Processual) - Faculdade de Direito da Universidade de São Paulo, São Paulo, 2009.

LOPES JÚNIOR, Aury. Direito ao processo penal no prazo razoável. Revista Brasileira de Ciências Criminais, São Paulo, v. 15, n. 65, p. 209-250, mar./abr. 2007.

MENDONÇA, Andrey Borges de. Prisão e outras medidas cautelares pessoais. São Paulo: Método, 2011.

MOURA, Maria Thereza Rocha de Assis. Habeas corpus na reforma do Código de Processo Penal. Revista do Advogado, v. 113, p. 83-91, 2011.

NAKAHARADA, Carlos Eduardo Mitsuo. Prisão preventiva: direito à razoável duração e necessidade de prazo legal máximo. Dissertação (Mestrado em Direito Processual) - Faculdade de Direito da Universidade de São Paulo, São Paulo, 2015.

NICOLA, Francesco de Santis di. Ragionevole durata del processo e rimedio effetivo. Napoli: Jovene, 2013.

NICOLITT, André Luiz. A duração razoável do processo. 2. ed. São Paulo: Revista dos Tribunais, 2014.

PALMA, Juliana Bonacorsi de; FEFERBAUM, Marina; PINHEIRO, Victor Maciel. Meu trabalho precisa de jurisprudência? Como posso utilizá-la? In: QUEIROZ, Rafael Mafei Rabelo. FEFERBAUM, Marina (coord.). Metodologia jurídica: um roteiro prático para trabalhos de conclusão de curso. São Paulo: Saraiva, 2012.

PASTOR, Daniel R. El plazo razonable en el processo del Estado de Derecho: una investigación acerca del problema de la excessiva duración del processo penal y sus posibles soluciones. Buenos Aires: Ad-Hoc, Konrad - Adenauer Stiftung, 2002.

PRADO, Geraldo. Excepcionalidade da prisão provisória. In: FERNANDES, Og (org). Medidas cautelares no processo penal, prisões e suas alternativas. São Paulo: Revista dos Tribunais, 2012, p. 121-123.

PIRES, Álvaro. Amostragem e pesquisa qualitativa: ensaios teóricos e metodológicos. In: POUPART, Jean; DESLAURIERS, Jean-Pierre; GROULX, Lionel-H; LAPERRIERE, Anne; MAYER, Robert; PIRES, Alvaro (org.). A pesquisa qualitativa: enfoques epistemológicos e metodológicos. Tradução Ana Cristina Nasser. Petrópolis: Vozes, 2008. 
QUEIROZ, Rafael Mafei Rabelo. Monografia jurídica: passo a passo. São Paulo: Método, 2015.

REALE, Miguel. Lições preliminares de Direito. 24. ed. São Paulo: Saraiva, 1999.

ROSA, Alexandre Morais da; SILVEIRA FILHO, Sylvio Lourenço da. Medidas compensatórias da demora jurisdicional: a efetivação do direito fundamental à duração razoável do processo penal. Rio de Janeiro: Lumen Juris, 2014.

RYU, Daiana Santos. O direito ao desencarceramento do acusado preso cautelarmente, caso não seja julgado no prazo razoável: análise dos critérios utilizados para aferição do excesso de prazo da prisão cautelar na jurisprudência dos Tribunais Superiores brasileiros. Dissertação (Mestrado em Direito Processual) - Faculdade de Direito da Universidade de São Paulo, São Paulo, 2018.

SANGUINÉ, Odone. Prisão cautelar, medidas alternativas e direitos fundamentais. Rio de Janeiro: Forense, 2014.

SHIMIZU, Bruno. Sobre o cárcere, o judiciário e irresponsabilidades. Boletim IBCCRIM, São Paulo, v. 23, n. 274, p. 20-21, set. 2015.

SILVA, José Afonso da. Curso de Direito Constitucional Positivo. 30. ed. São Paulo: Malheiros, 2007.

TUCCI, Rogério Lauria; DELMANTO JUNIOR, Roberto. Sistematização das medidas cautelares processuais penais. Revista do Advogado, São Paulo, v. 24, n. 78, p. 111-122, set. 2004. 


\section{Informações adicionais e declarações da autora}

Agradecimentos (acknowledgement): Agradeço à Jaqueline Nishi e ao Carlos Alcântara pelas considerações críticas que contribuíram ao aprimoramento deste artigo.

Declaração de conflito de interesses (conflict of interest declaration): a autora declara que não há conflitos de interesse na realização das pesquisas expostas e na redação deste artigo.

Declaração de autoria e especificação das contribuições (declaration of authorship): todas e somente as pessoas que atendem os requisitos de autoria deste artigo estão listadas como autores; todos os coautores se responsabilizam integralmente por este trabalho em sua totalidade.

Declaração de ineditismo e originalidade (declaration of originality): a autora assegura que o texto aqui publicado não foi divulgado anteriormente em outro meio e que futura republicação somente se realizará com a indicação expressa da referência desta publicação original; também atesta que não há plágio de terceiros ou autoplágio. Este artigo é versão parcial adaptada e revisada de: RYU, Daiana Santos. O direito ao desencarceramento do acusado preso cautelarmente, caso não seja julgado no prazo razoável: análise dos critérios utilizados para aferição do excesso de prazo da prisão cautelar na jurisprudência dos Tribunais Superiores brasileiros. Dissertação (Mestrado em Direito Processual). Faculdade de Direito, Universidade de São Paulo, São Paulo, 2018. 


\section{Dados do processo editorial}

(http://www.ibraspp.com.br/revista/index.php/RBDPP/about/editorialPolicies)

- Recebido em: $17 / 07 / 2018$

- Controle preliminar e verificação de plágio: 17/07/2018

- Avaliação 1: 30/07/2018

- Avaliação 2: 01/08/2018

- Avaliação 3: 04/08/2018

- Avaliação 4: 16/08/2018

- Deslocamento ao V5N1 e aviso autora: 22/09/2018

- Decisão editorial preliminar: $19 / 10 / 2018$

- Retorno rodada de correções: 30/11/2018

- Decisão editorial final: 02/12/2018

\section{Equipe editorial envolvida}

- Editor-chefe: (VGV)

- Editora-assistente: 1 (MJV)

- Revisores: 4

\section{COMO CITAR ESTE ARTIGO:}

RYU, Daiana Santos. Prisão cautelar e prazo razoável na jurisprudência dos Tribunais Superiores brasileiros. Revista Brasileira de Direito Processual Penal, Porto Alegre, vol. 5, n. 1, p. 389-438, jan./abr. 2019. https://doi.org/10.22197/rbdpp.v5i1.176

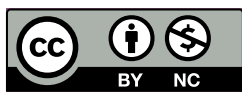

Esta obra está licenciada com uma Licença Creative Commons Atribuição-NãoComercial 4.0 Internacional. 